Research Report

\title{
Muscarinic receptor type 1 (M1) stimulation, probably through KCNQ/Kv7 channel closure, increases spontaneous GABA release at the dendrodendritic synapse in the mouse accessory olfactory bulb
}

\author{
Yoshito Takahashi", and Hideto Kaba* \\ * Department of Physiology, Kochi Medical School, Nankoku, Kochi 783-8505, Japan \\ \# Division of Adaptation Development, Department of Developmental Physiology, National Institute for Physiological Sciences, Okazaki \\ 444-8585, Japan
}

Address correspondence to: Yoshito Takahashi, Department of Physiology, Kochi Medical School, Nankoku, Kochi 783-8505, Japan; Telephone and FAX: +81-88-880-2307; E-mail: yuutarot@yahoo.co.jp

Number of text pages (including figure pages): 68

Number of figures: 8

With supplementary text (16 pages) and a supplementary figure

\begin{abstract}
Cholinergic modulation of spontaneous GABAergic currents (mIPSC) was studied using whole-cell patch methods in mouse accessory olfactory bulb slices. Carbachol (above $100 \mu \mathrm{M}$ ) administration produced an increase in the mIPSC frequency in mitral cells, but did not affect the responses of mitral cells to GABA. The carbachol effect persisted in the presence of combined ionotropic and metabotropic glutamatergic receptor antagonists. The carbachol effect was reduced by the muscarinic receptor type-1 and -4 (M1, M4) antagonist pirenzepine (10 $\mu \mathrm{M})$, but not by the $\mathrm{M} 2$ and $\mathrm{M} 4$ antagonist himbacine $(10 \mu \mathrm{M})$. The KCNQ/Kv7 potassium channel openers retigabine $(80 \mu \mathrm{M})$ and diclofenac $(300 \mu \mathrm{M})$ blocked the carbachol action, while the KCNQ potassium channel blocker XE-911 (20 $\mu \mathrm{M})$ increased the mIPSC frequency. XE-911's action persisted in the presence of glutamate receptor blockers. In the presence of carbachol, mIPSCs were abolished by $\mathrm{Ni}(200 \mu \mathrm{M})$, while being insensitive to the calcium channel blocker nimodipine $(30 \mu \mathrm{M})$, suggesting a role for R-type calcium channels in the GABA release. These results suggest that carbachol closed $\mathrm{KCNQ}$ channels by stimulating $\mathrm{M} 1$ receptors on granule cell dendrites, and the resulting depolarized and unstable membrane promoted calcium influx, thus increasing the GABA release. The possible role of acetylcholine in facilitating formation of a pheromone memory in mice is also discussed.
\end{abstract}

\section{Classification Terms}

Section: Neurophysiology

Key words: M-current, Pheromone, mIPSC, Mitral cell, Granule cell

\section{Abbreviations}

AC, adenylate cyclase; ACh, acetylcholine; AOB, accessory olfactory bulb; AP3, DL-2-amino-3-phosphonopropionic acid; BAPTA 1,2-bis-(2-aminophenoxy)-ethane-N,N,N',N'-tetraacetic acid; CNQX, 6-cyano-7-nitroquinoxaline-2,3-dione; D-AP5,

$\mathrm{D}$-2-amino-5-phosphonovaleric acid; CNS, central nervous system; 4-DAMP, 4-diphenylacetoxy- $\mathrm{N}$-methylpiperidine methiodide; DMSO, dimethyl sulfoxide; IP3, inositol 1,4,5-trisphosphate; K-S test, Kolmogorov-Smirnov test; mIPSC, miniature inhibitory post-synaptic current; PLC, phospholipase C; MCPG, (RS)- $\alpha$-methyl-4-carboxyphenylglycine; OB, olfactory bulb; TEA, tetra-ethyl ammonium; TTX, tetrodotoxin

\section{Introduction}

The accessory olfactory bulb (AOB) is the first central nervous system (CNS) relay for processing pheromonal sensory information (Luo et al., 2003). Although AOB is not present in humans (Meisami et al., 1998), it is an attractive region for study because of its simple structure, consisting of only three types of neurones (Mori, 1987) and its implicated functions such as information integration (Xu et al., 2005; Hendrickson et al., 2008) or memory storage (Kaba et al., 1994; Matsuoka et al., 2004; Binns and Brennan, 2005)

The mitral cell, the relay and output neurone in the AOB, has several long dendrites that receive sensory input. Along the length of the dendrites, numerous dendrodendritic reciprocal synapses are made with the dendrites of interneurones (granule cells). Glutamate is released from the mitral cell, while GABA is released from the granule cell (Jia et al., 1999; Taniguchi and Kaba, 2001). Spontaneous release of GABA from granule cells can be recorded as chloride currents in mitral cells using whole-cell recording; neuromodulators can increase the spontaneous mIPSC frequency via stimulation of noradrenergic $\alpha_{1}$ receptors (Araneda and Firestein, 2006) or mGluR1 metabotropic glutamate receptors (Castro et al., 2007).

The neuromodulator acetylcholine (ACh) has been implicated in attention and memory formation (Furey et al., 2000). Anatomical studies in rodents suggest that cholinergic centrifugal fibres terminate in the AOB (Carson and Burd, 1980; Macrides et al., 1981). These most likely originate from basal forebrain magnocellular neurones in the nucleus of the horizontal limb of the diagonal band (HDB; Macrides et al., 1981) or hypothalamic neurones in the bed nucleus of stria terminalis
(BNST; de Olmos et al., 1978). These two regions are in close proximity. Further, intrinsic cholinergic neurones, though rare, are found in the granule cell layer (Ojima et al., 1988) of the AOB. Muscarinic receptor mRNAs are expressed in the AOB (strong M1 and M4; weak M3: Buckley et al., 1988). Confirmed actions of $\mathrm{ACh}$ in the $\mathrm{AOB}$, however, have not been demonstrated. Though cholinergic action increases spontaneous mIPSCs in the olfactory bulb (Castillo et al., 1999; Ghatpande et al., 2006), this has not been shown in the AOB. As the effects of some cholinergic receptors are linked to the phospholipase C (PLC) pathway via the Gq11G-protein (see Caulfield and Birdsall, 1998 for review), we hypothesized that cholinergic stimulation has actions on mIPSCs similar to mGluR1 and noradrenergic $\alpha_{1}$ receptors stimulations that are also linked to Gq11G-protein. The current work tests this hypothesis and examines the mechanisms that underlie increases in spontaneous mIPSC frequency occurring via cholinergic stimulation in the AOB.

\section{Results}

Carbachol administration increased the frequency of spontaneous mIPSCs in mitral cells

Spontaneous inward currents (ranging from 0 to $3 \mathrm{~Hz}$ in frequency, mean of cells employed for analysis, $\mathrm{n}=30,0.8 \pm 0.8[\mathrm{SD}] \mathrm{Hz}$ ) were observed in whole-cell recordings made from mitral cells. Cells with a very low frequency of spontaneous currents (fewer than one per $30 \mathrm{~s}$ ) were not included in the analysis. When the holding potential was changed from -70 $\mathrm{mV}$ to $+30 \mathrm{mV}$, the current reversed polarity around $0 \mathrm{mV}$, which is the 
chloride equilibrium potential under the following recording conditions: extracellular Cl: $137 \mathrm{mM}$, intracellular $\mathrm{Cl}$ : $162 \mathrm{mM}, 58 \log (137 / 162)=-4.39$ $\mathrm{mV}$ (Fig. 1A). Bicuculline methiodide $(20 \mu \mathrm{M})$, a GABA receptor blocker, nearly abolished the spontaneous currents $(n=4$, Fig. 1B) completely. These findings suggest that the spontaneous currents are mediated by the opening of $\mathrm{GABA}_{\mathrm{A}}$ chloride channels. Thus, they are the so-called mIPSCs (GABA mediated currents recorded in the presence of TTX, though they were not miniature; see below).

Carbachol $(200 \mu \mathrm{M})$ application produced a marked increase in spontaneous mIPSC frequency. Eleven out of 21 cells had at least one time window (see Experimental procedures) with significant frequency increase by Kolmogorov-Smirnov test of inter-event interval cumulative plots (Fig. $1 \mathrm{Ca}, \mathrm{c})$. However in some carbachol applied cells ( 6 out of 21 cells), the frequency did not show any increase or even showed a run down (compared with 7 out of 9 cells in control vehicle applied cells). Bicuculline abolished the spontaneous currents ( 10 out of 10 cells), suggesting that the spontaneous currents increasing in frequency were also GABAergic and were not contaminated by others such as glutamatergic currents. The extent of increase and the latency of response varied among cells (Fig.1Ca). The responding cells tended to show long-lasting responses. Without any drug application, the mIPSC frequency tended to increase gradually in the first 5 min after the recording patch formation and run down slowly thereafter (Fig. $1 \mathrm{Cb})$. To avoid this run-down, the carbachol applications and the data collection for analysis were done in the most stable phase, which occurred between 10 and $30 \mathrm{~min}$ after the patch formation.

The average baseline current frequency of recorded cells before any drug application was $0.74 \pm 0.69 \mathrm{~Hz}$ in the carbachol-applied group, and $1.04 \pm 0.95 \mathrm{~Hz}$ in the vehicle applied control group; these were not significantly different (two tailed t-test $P=0.23$ ). The average current frequencies following carbachol or vehicle application were (in $\mathrm{Hz} \pm \mathrm{SD})$ : carbachol group $0.67 \pm 0.70(0-3 \mathrm{~min}$ after $), 1.00 \pm 1.07$ (3-6 min), 1.07 $\pm 1.35(6-9 \mathrm{~min})$; control group $0.70 \pm 0.74(0-3 \mathrm{~min}), 0.57 \pm 0.56(3-6 \mathrm{~min})$, $0.48 \pm 0.48(6-9 \mathrm{~min})$.

The distribution of current frequency change values was skewed with a subgroup of non-responsive cells and was not Gaussian (skewness, 2.54, Fig. 1D). Therefore, the nonparametric Mann-Whitney U-test was used to detect significance (see Experimental procedures). This method for analysis demonstrated that carbachol $(200 \mu \mathrm{M})$ significantly increased the mIPSC frequency compared with vehicle application (carbachol, $\mathrm{n}=21$, control, $\mathrm{n}=9$; frequencies increased by $0.4 \pm 1.1 \mathrm{vs} .-0.5 \pm 0.5 \mathrm{~Hz}, P<$ 0.0001 , U-test; Fig 1E). The $200 \mu \mathrm{M}$ concentration seemed not to saturate the carbachol action because a higher concentration (up to $1 \mathrm{mM}$ ) in later experiments resulted in fewer unresponsive cells and reduced latencies (9 out of 11 cells with $1 \mathrm{mM}$ application had at least one time window with a significant increase in frequency).

Though rarely, gigantic currents were observed (Fig 1F). Less than $3 \%$ of currents in any recording were giant currents with both amplitude larger than $100 \mathrm{pA}$ and width greater than $500 \mathrm{~ms}$. The giants appeared independently of carbachol applications (carbachol $n=21,0.6 \pm$ 0.8 (SD) $\%$ of the total events; control $\mathrm{n}=9,1.1 \pm 1.5$ (SD) $\%$ : t-test $\mathrm{p}=$ 0.39 ). They were probably caused by synchronous GABA release, but this could not be tested because their generations were rare and unpredicted.

Carbachol also increased the current amplitudes in some cells The mean current amplitude in each base time window was $108 \pm 46 \mathrm{pA}$ in the carbachol group $(\mathrm{n}=21)$, and $98 \pm 22 \mathrm{pA}$ in the control group $(\mathrm{n}=9)$, and these values were not significantly different $(P=0.48$, t-test). The current amplitude change ratios (amplitude mean value in any time windows/amplitude mean value in base time window) were: carbachol group $(\mathrm{n}=21), 1.6 \pm 2.6(0-3 \mathrm{~min}), 1.6 \pm 2.6(3-6 \mathrm{~min}), 1.7 \pm 3.0(6-9 \mathrm{~min})$; control group $(\mathrm{n}=9), 1.1 \pm 0.3(0-3 \mathrm{~min}), 0.9 \pm 0.2(3-6 \mathrm{~min}), 1.0 \pm 0.2$ (6-9 $\mathrm{min})$. Though large amplitude increases were occasionally seen (Fig. 2A), t-tests did not show any significant differences (carbachol $\mathrm{n}=21$, control $\mathrm{n}=9$; 0-3 $\mathrm{min}, P=0.32 ; 3-6 \mathrm{~min}, P=0.30 ; 6-9 \mathrm{~min}, P=0.26$ ). Also U-tests, by pooling the amplitude change ratios in each group as in the frequency analysis, did not show any significance (carbachol, $\mathrm{n}=21$, control, $\mathrm{n}=9$; amplitude change ratios $1.6 \pm 2.7$ vs. $1 \pm 0.2, P=0.60$, U-test).

Cumulative plot analysis of mIPSC amplitudes was done on selected cells whose recordings were the most stable (carbachol application $\mathrm{n}=10$, control $\mathrm{n}=6$ ). Carbachol group cells were those with good (more than two time windows with increased current frequency compared with the base time window) response to carbachol. For each cell, four curves were plotted for the time windows of base, 0-3, 3-6, and 6-9 min. In each cell, curve shifts in respect to the base time window were diagnosed by the K-S test $(P<0.05$, two tailed) as: leftward significant, rightward significant with $P<0.05$, or no significant shift (leftward significant shift indicates a decrease in current amplitude while rightward significant shift indicates an increase in current amplitude). In the ten cells that had carbachol application, a total of 30 curves were assessed for a curve shift; 14 curves showed a leftward shift, 5 curves showed a rightward shift, 1 curve showed a crossing (Fig. 2B) with both significant left and right-ward shifts, and 10 curves did not show any significant shift (Fig. 2B). In the 6 control cells, a total of 18 curves were assessed for the shift; 7 curves showed a leftward shift and the remaining 11 curves did not show a significant shift (Fig. 2B). Of interest is the observation that curves for both the carbachol and control cells showed a similar frequency of leftward shift, while the rightward shift was only observed in the carbachol-exposed cells ( 4 cells out of 10 carbachol-exposed cells, one curve each from 3 cells and 2 curves from 1 cell). The leftward shifts (decreases in mIPSC amplitude) were carbachol-independent, as they were observed in both carbachol and control cells with similar frequency ( $47 \%$ vs. $39 \%$ ).

We considered two mechanisms to explain the increase in current amplitude resulting from carbachol administration. The first mechanism considered was the selective action of carbachol on dendrodendritic synapses near the recording site resulting in increases in large currents that were not reduced in amplitude by electronic attenuation. This is possible because more cholinergic fibres are seen in the mitral cell body side than in the cell's dendritic tip side (Carson and Burd, 1980). The second mechanism consists of a quantal increase in the GABA released affecting postsynaptic currents. This increase may be achieved by increasing synaptic vesicle content or by increasing the number of vesicles released for a mIPSC. Analysis of current shapes suggested that a single synapse could handle multiple levels of transmission (see below). It is also possible that greatly increased presynaptic calcium works on sites other than the known release triggers to increase the pool of readily releasable vesicles (Sakaba, 2008). However, frequency change value to amplitude change ratio plots did not show a correlation (Fig. 2C), suggesting amplitude and frequency changes are independent processes. Thus, amplitude changes are probably dependent on the current profiles of a subpopulation of granule cells that are activated by carbachol, but not dependent on presynaptic calcium availability.

\section{Carbachol administration did not change the sensitivity of mitral cells to GABA}

The rise in the amplitude of mIPSCs by carbachol administration posed the possibilities that carbachol either acted at presynaptic sites (on granule cells) to increase quantal GABA release, or at post synaptic sites (on mitral cells) to increase their sensitivity to the released GABA. To clarify this matter, we next tested whether or not carbachol application increased the response of mitral cell to puff-applied GABA (Fig. 3A). The amplitude increase ratios (see Methods) for the carbachol group $(n=7)$ were $1.08 \pm$ 0.17 (mean $\pm \mathrm{SD}$ ) at $0-3 \mathrm{~min}, 1.10 \pm 0.25$ at $3-6 \mathrm{~min}$, and $1.16 \pm 0.45$ at $6-9$ min, whereas the ratios for the control group $(n=6)$ were $0.85 \pm 0.34$ at $0-3$ $\mathrm{min}, 1.09 \pm 0.32$ at $3-6 \mathrm{~min}$, and $0.96 \pm 0.71$ at $6-9 \mathrm{~min}$. No significant differences were seen in the ratios of any time windows between the carbachol and control groups (t-test: 0-3 min, $P=0.67$; 3-6 min, $P=0.57$; 6-9 $\min , P=0.81$; Fig. $3 \mathrm{~B}$ ). Non-parametric analysis of the puff current amplitude, using the same method as the frequency analysis (replacing frequency change values with the amplitude change ratio values) also failed to show a significant rise by carbachol application compared with vehicle-only application ( $1 \mathrm{mM}$ carbachol, $\mathrm{n}=7$, control, $\mathrm{n}=6$; amplitude change ratios $1.1 \pm 0.3$ vs. $1.0 \pm 0.5, P=0.37$, U-test), while the background frequency (see Methods) of mIPSCs showed a significant increase in the carbachol group compared with the vehicle group $(1 \mathrm{mM}$ carbachol, $\mathrm{n}=7$, control, $\mathrm{n}=6$; frequencies increased by $2.4 \pm 2.1$ vs. 0.5 $\pm 0.6 \mathrm{~Hz}, P=0.001, \mathrm{U}$-test). In some cells, increases in both the frequency and amplitude of mIPSCs were robust even without an increase in the amplitude of the GABA puff current (Fig. 3C). We can thus conclude that the influence of carbachol upon release sites on granule cells and not upon the sensitivity of mitral cells to GABA underlies the observed increases in spontaneous mIPSC frequency in mitral cells.

\section{The carbachol action was mediated by $\mathrm{M} 1$ receptors}

Scopolamine $(100 \mu \mathrm{M})$, a muscarinic antagonist, blocked the action of 1 $\mathrm{mM}$ carbachol (scopolamine, $\mathrm{n}=7$, control, $\mathrm{n}=7$; frequencies increased by $-0.3 \pm 0.6$ vs. $0.5 \pm 0.6 \mathrm{~Hz}, P=0.001$, U-test; Fig. 4A). Application of pilocarpine $(300 \mu \mathrm{M})$, a muscarinic agonist, resulted in increases in the mIPSC frequency (pilocarpine, $\mathrm{n}=4$, control, $\mathrm{n}=5$; frequencies increased by $3.9 \pm 3.5$ vs. $-0.1 \pm 1.2 \mathrm{~Hz}, P=0.0004$, U-test; Fig. 4 A). These results demonstrate the carbachol action to be muscarinic.

We next tested which muscarinic receptor subtypes (M1 M5) were involved. Pirenzepine at $10 \mu \mathrm{M}$ (an antagonist for M1 and M4) blocked the action of $100 \mu \mathrm{M}$ carbachol (pirenzepine, $\mathrm{n}=7$, control, $\mathrm{n}=6$; frequencies increased by $-0.4 \pm 0.7$ vs. $0.8 \pm 1.5 \mathrm{~Hz}, P=0.001$, U-test; Fig. 4A). 
Himbacine, an antagonist for M2 and M4 receptors, could not block the $100 \mu \mathrm{M}$ carbachol action (himbacine $1 \mu \mathrm{M}, \mathrm{n}=3$, frequencies increased by $0.0 \pm 1.0 \mathrm{~Hz} ; 10 \mu \mathrm{M} \mathrm{n}=1,1.0 \pm 0.5 \mathrm{~Hz}$; Fig. 4B). The M3 antagonist, 4-DAMP, also could not inhibit the $100 \mu \mathrm{M}$ carbachol action (4-DAMP $30 \mathrm{nM}, \mathrm{n}=2$, frequencies increased by $1.1 \pm 1.4 \mathrm{~Hz} ; 300 \mathrm{nM}, \mathrm{n}$ $=2,0.6 \pm 0.9 \mathrm{~Hz}$; Fig. 4B).

The demonstrated sensitivity to pirenzepine suggests M1 or M4 as likely candidates, while insensitivity to himbacine or 4-DAMP suggests M2, M3, and M4 as unlikely. Taken together, these response profiles to muscarinic antagonists suggest that the receptor subtype involved in the carbachol action was M1.

\section{Carbachol acted on granule cells and possibly also on mitral} cells to increase the mIPSC frequency

Two possibilities were considered to explain the mechanisms of carbachol's actions upon the mIPSCs. The first possibility is that carbachol may act directly on cholinergic receptors on granule cells to increase GABA release. The second is that carbachol may act upon mitral cell receptors to increase glutamate release, which would then stimulate granule cell GABA release (Fig. 5A). The third is that both sites are involved (as in the olfactory bulb; Ghatpande et al., 2009).

We tested the action of carbachol in the presence of glutamatergic blockers. Glutamatergic actions can be mediated by either ionotropic or metabotropic glutamate receptors. Among the metabotropic glutamate receptors, mGluR1 alone is responsible for increases in spontaneous GABA release from granule cells (Castro et al., 2007). Thus, we applied carbachol together in the presence of antagonists of ionotropic glutamate receptors (kynurenic acid, CNQX and D-AP5) and mGluR1 receptors (AP3 and MCPG). Carbachol (1 mM) application, in the presence of kynurenic acid $(5 \mathrm{mM})$ and AP3 $(200 \mu \mathrm{M})$, still caused an trend of increase in the spontaneous mitral cell current frequency (carbachol, $\mathrm{n}=8$, control, $\mathrm{n}=5$; frequencies increased by $0.9 \pm 2.4$ vs. $0.1 \pm 1 \mathrm{~Hz}, P=$ 0.06, U-test; Fig. 5B). On the other hand, the carbachol's action was not significantly reduced by a mixture of glutamatergic blockers $(5 \mathrm{mM}$ kynurenic acid, $30 \mu \mathrm{M}$ CNQX, $50 \mu \mathrm{M}$ D-AP5, and $500 \mu \mathrm{M} \mathrm{MCPG,} \mathrm{n}=8$, vehicle, $\mathrm{n}=6$; direct bath application of $300 \mu \mathrm{M}$ carbachol in both groups, frequencies increased by $-0.1 \pm 0.6$ vs. $0.3 \pm 1.2 \mathrm{~Hz}, P=0.83$, U-test; Fig. 5B). Although the blockers possibly reduced the carbachol effect, apparent mIPSC frequency increases were observed in some cells in the presence of the glutamatergic blockers ( Fig. 5B).

We considered a role of mitral cells because their depolarization to $+30 \mathrm{mV}$ increased the mIPSC frequency (Fig. 5C, left), and application of glutamic acid, the transmitter of mitral cell, also increased the current frequency (Fig. 5D). However, in the presence of the mixed glutamatergic blockers, neither the $+30 \mathrm{mV}$ mitral cell depolarization (in the presence of $5 \mathrm{mM}$ kynurenic acid $+200 \mu \mathrm{M} \mathrm{AP3}+50 \mu \mathrm{M} \mathrm{CNQX}+$ $50 \mu \mathrm{M}$ D-AP5, $\mathrm{n}=5$, Fig. $5 \mathrm{C}$ right); ) nor the $100 \mu \mathrm{M}$ glutamic acid application (in the presence of $5 \mathrm{mM}$ kynurenic acid, $30 \mu \mathrm{M} \mathrm{CNQX}, 50 \mu \mathrm{M}$ $\mathrm{D}-\mathrm{AP} 5$, and $500 \mu \mathrm{M} \mathrm{MCPG}, \mathrm{n}=3$ ) increased the mIPSC frequency. These suggest that mitral to granule cell transmission was successfully blocked by the mixed glutamatergic blockers. Furthermore, loading of recorded mitral cells with intracellular BAPTA to block the cell's glutamate release failed to inhibit the effects of $100 \mu \mathrm{M}$ carbachol (intracellular $2.5 \sim 5 \mathrm{mM}$ BAPTA, $\mathrm{n}=3$, frequency increased by $1.9 \pm 0.8 \mathrm{~Hz}$ ). However, glutamate released by other mitral cells may stimulate granule cells.

These results suggest that the carbachol directly acts on granule cells to stimulate their GABA release. Possibly, as reported in the olfactory bulb (Ghatpande et al., 2009), carbachol acts on mitral cells to stimulate their glutamate release, which then stimulate GABA release by granule cells. A role of periglomerular cells (another GABA neuron in AOB) was not ruled out but is less likely because cholinergic fibres are not seen in the periglomerular layer (Carson and Burd, 1980).

\section{Blockade of $L$ or T-type calcium channels or intracellular calcium release did not reduce the carbachol's action on the mIPSC frequency}

We tested the hypothesis that the carbachol action increased calcium channel activity in granule cells, thereby increasing calcium influx and GABA release. The involved calcium channel could be directly coupled, or not, to vesicular release. Uncoupled calcium channels can increase the vesicle release probability by increasing the calcium concentration in the release terminal. Directly coupled channels cannot be tested because, if a blocker is applied, the spontaneous mIPSCs will disappear. We therefore sought to inhibit calcium channels that are unlikely to be directly coupled to vesicle release.

The L-type calcium channel blocker nifedipine, and the T-type blocker amiloride, or nickel chloride $(100 \mu \mathrm{M})$ all failed to significantly reduce carbachol's action ( $30 \mu \mathrm{M}$ nifedipine, $\mathrm{n}=10$, vehicle, $\mathrm{n}=8 ; P=$
$0.29 ; 500 \mu \mathrm{M}$ amiloride, $\mathrm{n}=4$, vehicle $\mathrm{n}=4 ; P=0.75 ; 100 \mu \mathrm{M} \mathrm{Ni}, \mathrm{n}=$ 12 , control, $\mathrm{n}=5 ; P=0.84$, U-test; see Supplement for details). On the other hand, carbachol significantly increased the current frequency in the presence of $20 \mu \mathrm{M}$ mibefradil, a T-type blocker (direct bath application of $300 \mu \mathrm{M}$ carbachol, $\mathrm{n}=4$, vehicle only application, $\mathrm{n}=3$; frequencies increased by $0.2 \pm 0.4$ vs. $-0.8 \pm 1.2 \mathrm{~Hz}, P=0.02$, U-test).

In quest of the calcium source that enhanced the spontaneous GABA release, we also tried blockade of intracellular calcium release. At $15 \mu \mathrm{M}, 2$-APB blocks inositol 1,4,5-trisphosphate $\left(\mathrm{IP}_{3}\right)$ receptor-mediated calcium release from endoplasmic reticulum calcium stores (Maruyama et al., 1997). However, no significant differences in the carbachol effect were shown in the presence of $2-\mathrm{APB}$ at 15,75 or $150 \mu \mathrm{M}(>20 \mathrm{~min})$ compared with its vehicle $(15 \mu \mathrm{M} 2-\mathrm{APB}, \mathrm{n}=7$, vehicle ethanol only, $\mathrm{n}=4 ; 1 \mathrm{mM}$ carbachol application in both wings, frequencies increased by $0.7 \pm 1.7 \mathrm{vs}$. $-0.3 \pm 1.5 \mathrm{~Hz}, P=0.10$, U-test: see also results for 75 or $150 \mu \mathrm{M} 2-\mathrm{APB}$ in Supplement).

However, the mIPSCs were abolished almost totally by $5 \mathrm{mM}$ nickel chloride ( $\mathrm{n}=6$; Fig. $6 \mathrm{C}$ ) even when the mIPSC frequency was enhanced by carbachol. This suggests that extracellular calcium via calcium channels other than L or T-type are necessary for generation of the mIPSCs and of the increased currents resulting from carbachol administrations.

To ascertain the source of calcium responsible for spontaneous GABA release, blockers of cell calcium entry were investigated (See also Supplement). The mitral cell currents were almost completely abolished by nickel chloride at $200 \mu \mathrm{M}$, while cadmium or cobalt at the same concentration was not effective (Fig. 6B, C). This suggests the involvement of R or T-type calcium channels, which are sensitive to nickel (Foehring et al., 2000). The $\mathrm{L}$ and T-type blockers, nifedipine $(30 \mu \mathrm{M}, \mathrm{n}=6)$ or nimodipine ( $30 \mu \mathrm{M}, \mathrm{n}=5$; Fig. $6 \mathrm{~B}, \mathrm{C})$ were not inhibitory upon the mIPSCs. This implicate the R-type over the T-type calcium channel because the R-type channel current is not responsive to block by nimodipine, while the T-type current is responsive (Randall and Tsien, 1997). Furthermore, the highly selective T-type calcium channel blocker, (-)-(R) enantiomer efonidipine (at saturating concentration, above $10 \mu \mathrm{M}, \mathrm{n}$ = 6; Fig. 6B, C; Perez-Reyes et al., 2009; Furukawa et al., 2004) failed to show any notable effect. Mixture of the P/Q-type calcium channel antagonist, the peptide omega-agatoxin IVA $(1 \mu \mathrm{M})$, and the N-type inhibitory peptide omega-conotoxin GVIA $(1 \mu \mathrm{M})$ had no notable influence upon the mIPSCs (Fig. 6B). Our findings thus implicate the role for R-type calcium channels in the generation of mIPSCs.

\section{$K C N Q$ channel antagonists increased the frequency of spontaneous mIPSCs, while KCNQ channel openers inhibited the increase of mIPSC frequency by carbachol}

The KCNQ (Kv7) channel is a potassium channel that is closed by muscarinic action (Delmas and Brown, 2005). The potassium current mediated via these channels is referred to as an M-current (from muscarinic). Potassium channel closure excites the neurone by depolarizing its membrane as well as by making the membrane more susceptible to depolarizing inputs. Barium (1 mM), which blocks KCNQ channels (Constanti et al., 1981), was bath applied and resulted in a marked increase in mIPSC frequency $(n=10$, Fig. 7A). Barium does enter through calcium channels, but compared with calcium, has negligible actions to release vesicles (Miledi, 1966). The marked effect of barium was also observed in the presence of a mixture of glutamatergic receptor inhibitors $(5 \mathrm{mM}$ kynurenic acid, $30 \mu \mathrm{M} C N Q X, 50 \mu \mathrm{M}$ D-AP5, and $500 \mu \mathrm{M}$ MCPG; $\mathrm{n}=3$ ), which should inhibit all of the glutamatergic receptors that are known to stimulate GABA release from granule cells (Castro et al., 2007). Furthermore, XE-991, a derivate of linodipine and a more potent and specific antagonist for the KCNQ channel (Elmedyb et al., 2007), increased the mIPSCs in the presence of the glutamatergic blockers $(5 \mathrm{mM}$ kynurenic acid, $30 \mu \mathrm{M}$ CNQX, $50 \mu \mathrm{M}$ D-AP5, and $500 \mu \mathrm{M}$ MCPG in perfusate; from 10 to $50 \mu \mathrm{M}$ XE-991, 7 out of 9 cells; Fig. 7A). This suggests that XE-991 closed the KCNQ channels on granule cells, depolarizing their membranes, and that the glutamatergic drive from mitral cells was then unnecessary for the increase in current frequency.

Retigabine $(80 \mu \mathrm{M})$, a KCNQ channel opener (expected to paralyse closure) inhibited the carbachol action (retigabine, $\mathrm{n}=6$, vehicle only, $\mathrm{n}=5$; frequencies increased by $-0.1 \pm 0.3$ vs. $1.6 \pm 2 \mathrm{~Hz}, P=$ 0.03 , U-test; Fig. 7B). This concentration of retigabine was expected not to show an observable effect on calcium channels (Rundfeldt and Netzer, 2000 ) and is in the range that sufficiently blocks epileptic activity in hippocampus slices (Dost and Rundfeldt, 2000). Retigabine possibly enhances GABA receptor sensitivity (Otto et al., 2002) and inhibits the excitability of granule cells. However, in agreement with the retigabine results, another KCNQ channel opener, diclofenac (Peretz et al., 2005) also blocked carbachol's action ( $300 \mu \mathrm{M}$ diclofenac, $\mathrm{n}=10$, vehicle ethanol only, $\mathrm{n}=6$; frequencies increased by $0.1 \pm 0.5$ vs. $0.7 \pm 1 \mathrm{~Hz}, P=0.02$, 
U-test; Fig. 7B). These consistent results suggest that both agents worked specifically via the opening of KCNQ channels.

KCNQ channel opening in neurones hyperpolarizes their membrane potential by $10 \mathrm{mV}$ (Otto et al., 2002). To rule out the possibility that hyperpolarization per se blocked carbachol's action, we used low potassium (1.13 mM instead of $2.5 \mathrm{mM}$ standard) external solution. The potassium equilibrium potential should be $20 \mathrm{mV} \operatorname{lower}\left(58 \log 2.5 /\left[\mathrm{K}_{\mathrm{in}}\right]\right.$ $\left.58 \log 1.13 /\left[\mathrm{K}_{\mathrm{in}}\right]=20\right)$, thus granule cell will be hyperpolarized to this extent with the low-potassium solution. However, the influence of carbachol was apparent even under these conditions $(n=4$, frequency increased by $0.5 \pm 0.6 \mathrm{~Hz}$; Fig. 7B).

Taken together, these results suggest that KCNQ openers, by their specific effect, inhibited carbachol's actions. And thus suggests carbachol's action is mediated by closing KCNQ channels.

\section{Analysis of the mIPSCs suggested that they are constructed by synchronized multiple quantum currents \\ The shapes of the mIPSCs varied greatly. Some had multiple small inward-current peaks, like a saw, while others had a notch when up-shooting to the peak (Fig.8A). These shapes suggest that a summation of smaller events underlie the observed currents. Current amplitude or area occurrence frequency histograms occasionally showed evenly spaced multiple peaks and dips (Fig.8B). Using Asertine analysis (Fig.8C), these were judged to be quantally distributed. An explanation for this is that synchronized multiple small quantum currents were constructing greater currents.}

These results suggest that dendrodendritic synapses in the AOB were not saturated by a single vesicle and can accommodate multiple levels of transmission. This is in contrast to findings in other areas of the CNS cortex (Silver et al., 2003).

\section{Discussion}

\section{A role for the KCNQ channel in the enhancement of the mIPSC} by carbachol administration

An increase in the mIPSCs by barium or XE-991 suggested that KCNQ channel was indeed operating at the synapse. As these actions were observed under the glutamatergic inhibitors, the granule cell is the likely site of action. Inhibition of carbachol's action by the KCNQ channel openers retigabine or diclofenac suggested that carbachol acts via the down-regulation of KCNQ channels. The down-regulation of KCNQ channels increases transmitter release (Lechner et al., 2003; Martire et al. 2004; Peretz et al., 2007; Zhang et al., 2009), and the link between muscarinic stimulation and KCNQ channel down-regulation is well-established (Delmas and Brown, 2005). It is therefore probable that carbachol down-regulates the activity of KCNQ channels in the granule cells and, through increased membrane depolarization, increases the open probability of membrane calcium channels, resulting in an increase in synaptic vesicle release.

We examined the role of T-type calcium channels, which open at relatively weak depolarization levels compared with other subtypes. In the presence of mibefradil, however, the carbachol effect persisted, ruling out the T-type as the sole calcium channel involved in the enhancement of mIPSCs. The granule cell depolarization thus probably activates a mixture of calcium channel subtypes. The R-type channel is especially implicated, as the pharmacological profile (Fig. 6B, C) suggests a dominant role for this channel in the current and as the R-type channel activates at relatively low depolarization threshold (Soong et al., 1993) compared with other subtypes of high-voltage activated channels.

In this study, actions of carbachol on mitral cell excitability were not studied. Thus, additional possibility that mIPSC was enhanced through mitral cell excitation still remains.

\section{Differences between the AOB and the olfactory bulb (OB)}

Our findings in the AOB are different from previous work in the $\mathrm{OB}$, where the carbachol-induced increase in spontaneous GABA currents was blocked by the intracellular calcium store blocker thapsigargin, suggesting that calcium released from internal stores stimulated GABA release (Ghatpande et al., 2006). In contrast, in the AOB, the intracellular calcium store blocker 2-APB did not inhibit the carbachol effect; instead, a different mechanism, the closure of KCNQ channels by M1 stimulation, was implicated. The difference in these studies possibly resulted from the ages of the animals. Ghatpande et al. used young rats (within $3 \mathrm{w}$ ), while we used mice older than $3 \mathrm{w}$. The expression of KCNQ3, a component of the neuronal KCNQ channel, continues to increase in the brain as the animal matures (Tinel et al., 1998). It is thus possible that the KCNQ pathway replaces the intracellular calcium pathway as the animal matures. Our result in the AOB was is in agreement with findings that the M1 ACh receptor is not linked to intracellular calcium stores in sympathetic neurones (Delmas and Brown,
2002). The AOB was also less sensitive to carbachol than the $\mathrm{OB}(50 \mu \mathrm{M}$ is sufficient for $300 \mu \mathrm{m}$ slice in mouse OB; Castillo et al., 1999), and we had to use carbachol concentrations higher than $100 \mu \mathrm{M}$ to see a reliable effect. This possibly results from fewer cholinergic fibres observed in the AOB external plexiform layer (site of the dendrodendritic synapses) compared with the OB (Carson and Burd, 1980; Ojima et al., 1988), or different $\mathrm{G}$ protein use downstream of M1 stimulation (Gudermann et al., 1997). These disparate findings constitute another line of evidence that the $\mathrm{AOB}$ and $\mathrm{OB}$ are significantly different and are worth investigating separately.

\section{Acetylcholine may facilitate pheromonal memory formation} The AOB dendrodendritic synapse is implicated in the plasticity of pheromonal memory (Brennan and Keverne, 1989; Kaba et al., 1994; Matsuoka et al., 2004). Female mice learn to give up responding to a mated male's pheromone at a critical period just after the mating and thereafter become insensitive to the pheromone (Leinders-Zufall et al., 2004). Noradrenaline released during mating has been proposed to facilitate this learning (Rosser and Keverne, 1985; Kaba and Keverne, 1988; Keverne and Riva, 1982). However, the learning is also possible in noradrenaline-deficient mice (Thomas and Palmiter, 1997). This implies the existence of alternative candidates for the facilitation of the learning. The carbachol effect in our study was similar to the actions of noradrenaline in the AOB (Araneda and Firestein, 2006). It is possible that acetylcholine and noradrenaline cooperate to facilitate learning in the AOB, as they do in the visual cortex (Kasamatsu, 1991).

\section{A hypothesis of how increases in the spontaneous release of GABA facilitate synaptic plasticity}

Given that GABA is widely accepted as the major inhibitory transmitter, it is understandable that one could be puzzled in how increases in GABAergic activity, which increase inhibition, could play a permissive role in plasticity. However, as long as we are uncertain about the exact local membrane potentials and chloride concentration in the mitral cell dendrites, we cannot determine whether the inputs from the granule cells are actually inhibitory, for with lower membrane potential below the chloride equilibrium potential $\left(58 \log \left[\mathrm{Cl}_{\mathrm{ex}}\right] /\left[\mathrm{Cl}_{\text {in }}\right]\right)$ or with higher intracellular chloride, the action of GABA is excitatory (Szabadics et al., 2006).

Assuming GABA to be inhibitory, we consider two possibilities to explain its role in promoting plasticity. The first possibility is that the inhibition by mIPSCs optimizes the sensory input by avoiding saturation and promising fidelity, so that the properly-transmitted high-frequency inputs are able to induce plasticity. The second possibility is that the facilitation of the spontaneous GABA release depletes the ready-releasable pool of GABA, and thus may desensitize granule cell dendrites from secreting GABA in response to trains of action potentials in the mitral cell dendrite, thus releasing the mitral cell from GABA inhibition. In any case, further study is needed to determine the role of spontaneous GABA currents in AOB plasticity.

In our experimental condition with chloride loaded mitral cells, mIPSCs may depolarize mitral cells and cause their glutamate release, which may facilitate the mIPSCs in a feed forward manner. On the other hand, mIPSCs should be more abundant in vivo without slicing. Thus our study could not precisely define the extent of the mIPSCs enhanced by acetylcholine in vivo.

\section{Conclusion}

The current study suggests that muscarinic stimulation, through the down-regulation of KCNQ channel activity, increases spontaneous GABA release from granule cells. This mechanism could play a role in pheromone memory formation. In a broader sense the AOB, because it has a simple structure, is a CNS region that may facilitate the study of memory. Since acetylcholine in the CNS is associated with memory disorders such as Alzheimer's disease, and the KCNQ channel in the CNS is associated with epileptic disorders such as benign familial neonatal convulsions (Biervert et al., 1998), understanding the precise mechanism underlying the synaptic plasticity evident in our system may greatly increase both the understanding of, and the therapeutic options for, these debilitating diseases.

\section{Experimental procedures \\ Ethical approval}

All experiments were carried out in accordance with the Kochi Medical School guidelines for care and use of laboratory animals. All efforts were made to minimize animal suffering and to reduce the number of animals used.

Slice preparation

Adult BALB/c mice ( 3 weeks to 3 months old) were sacrificed by cervical 
dislocation. Parasagittal AOB slices ( $275 \mu \mathrm{m}$ thick) were made with a linear tissue slicer (Pro7 Dosaka Japan) in ice-cold sucrose-replaced low calcium saline (sucrose $220 \mathrm{mM}$ replacing $\mathrm{NaCl}, \mathrm{CaCl}_{2}$ reduced to $0.25 \mathrm{mM}$ of external solution, see below). The slices were incubated in a holding chamber, gently bubbled with an $\mathrm{O}_{2}(95 \%)$ and $\mathrm{CO}_{2}(5 \%)$ gas mixture for at least $40 \mathrm{~min}$ at room temperature.

\section{Whole cell electrophysiological recording}

Methods for whole cell patch recording are similar as described elsewhere (Takahashi, 1990). Briefly, slices in a recording chamber (3 $\mathrm{ml}$ volume) were continuously perfused ( $2 \mathrm{ml} / \mathrm{min}$ during recordings) using a peristaltic pump (Gilson MINIPULS3, Middleton, USA). In later experiments, a gravity drip system with a slower perfusion rate was used. The perfused Ringer's solution consisted of (in $\mathrm{mM}$ ): $119 \mathrm{NaCl}, 2.5 \mathrm{KCl}, 2.5 \mathrm{CaCl}_{2}, 1.3$ $\mathrm{MgSO}_{4}, 1 \mathrm{NaH}_{2} \mathrm{PO}_{4}, 26.2 \mathrm{NaHCO}_{3}$, and 11 glucose. The $\mathrm{pH}$ was maintained at 7.4 by saturation of the external solution with an $\mathrm{O}_{2}(95 \%)$ and $\mathrm{CO}_{2}(5 \%)$ gas mixture at $300 \mathrm{Osm}$. In most experiments unless noted otherwise, $10 \mathrm{mM}$ tetra-ethyl ammonium (TEA) and $1 \mu \mathrm{M}$ tetrodotoxin (TTX) were added to the external solution ("standard external solution"). Recordings were performed at room temperature. In winter, experiments were heat controlled to $26^{\circ} \mathrm{C}$. Slices were viewed under an upright microscope (DM-LFS Leica, Wetzlar, Germany) and a CCD camera (C2400; Hamamatsu Photonics, Hamamatsu, Japan) using a 40× water immersion lens. Mitral cells were identified on the basis of their size (long axis greater than $20 \mu \mathrm{m}$ ), polygonal morphology, and their location in the middle and deep external plexiform layers. Patch pipettes with resistances of 2 to $8 \mathrm{M} \Omega$ were made from borosilicate glass capillaries (1B150F-4; WPI, Sarasota, FL, USA) using an electrode puller (P-97; Sutter Instruments, Novato, CA, USA) and then heat-polished. Pipettes were filled with an internal solution of (in mM): 140 CsCI, 10 HEPES, 5 EGTA, 3 ATP-Mg, and 0.5 GTP-Na ( $\mathrm{pH} 7.4$ ). Membrane currents were recorded in the whole-cell configuration (holding potential $=-70 \mathrm{mV}$ ). Whole cell current measurements were made using a patch-clamp amplifier (EPC9; Heka, Lambrecht, Germany). The sampling frequencies were $100 \mathrm{~Hz}$ (in most experiments) or $1 \mathrm{kHz}$ (to study current trace morphology). The filtering frequency was $3 \mathrm{kHz}$ and $\mathrm{R}_{\text {series }}$ was not compensated. Data sampling and analysis were performed on a personal computer using Pulse (Heka), PowerLab/4SP (AD Instruments, Australia), Mini Analysis (Synaptosoft), Excel (Microsoft) and StatView (SAS institute, Cary, USA).

\section{Chemicals}

If not otherwise noted, chemicals were dissolved in water or, if hydrophobic, in dimethyl sulfoxide (DMSO) at the highest concentration according to the supplier's data sheet, and stored in a $-20^{\circ} \mathrm{C}$ freezer. Chemicals (stock concentration, vehicle, and storage temperature in parenthesis) were purchased from the following sources: Sigma (St. Louis, USA), carbachol $\left(1 \mathrm{M}\right.$ or $100 \mathrm{mM}$ in water, $4^{\circ} \mathrm{C}$ prepared daily), ATP-Mg $(30 \mathrm{mM}$ in water, $4^{\circ} \mathrm{C}$, prepared daily), kynurenic acid (added directly to solution, sonicated), TEA-Cl $\left(1 \mathrm{M}\right.$ in water, $\left.4^{\circ} \mathrm{C}\right)$, amiloride (directly into solution, sonicated), DL-2-Amino-3-phosphonopropionic acid (AP3; $100 \mathrm{mM}$ in $1 \mathrm{~N} \mathrm{NaOHaq),}$ scopolamine (100 mM in water), bicuculline methiodide (10 $\mathrm{mM}$ in water, $4^{\circ} \mathrm{C}$ ), nifedipine ( $30 \mathrm{mM}$ in ethanol),

1,2-bis-(2-aminophenoxy)-ethane-N,N,N',N'-tetraacetic acid (BAPTA; 25 $\mathrm{mM}, 50 \mathrm{mM}$ CsOHaq), D-2-amino-5-phosphonovaleric acid (D-AP5; 50 $\mathrm{mM})$, mibefradil, himbacine (5 $\mathrm{mM}$ in ethanol),

6-Cyano-7-nitroquinoxaline-2,3-dione (CNQX; $50 \mathrm{mM}$ in DMSO), XE-991 $\left(100 \mathrm{mM}\right.$ in DMSO), glutamic acid $\left(10 \mathrm{mM}, 4^{\circ} \mathrm{C}\right), \mathrm{GABA}\left(1 \mathrm{mM}, 4^{\circ} \mathrm{C}\right)$, 4-Diphenylacetoxy-N-methylpiperidine methiodide (4-DAMP); Nakarai (Kyoto, Japan), TTX (100 $\mu \mathrm{M}$ in water), GTP Na $\left(5 \mathrm{mM}\right.$ in water, $4^{\circ} \mathrm{C}$, prepared daily), pilocarpine (50 $\mathrm{mM}$ in DMSO); Toronto Research Chemicals (North York, Canada), retigabine hydrochloride $(100$ or $50 \mathrm{mM}$ in water, $-20^{\circ} \mathrm{C}$ ); Wako (Osaka, Japan), D-AP5, diclofenac (100 mM in ethanol); Tocris (Bristol, UK), D-AP5 (5 mM in water, $\left.4^{\circ} \mathrm{C}\right)$,

(RS)- $\alpha$-methyl-4-carboxyphenylglycine (MCPG; $50 \mathrm{mM}$ in $0.1 \mathrm{~N} \mathrm{NaOH}$ ); Peptide Institute (Osaka, Japan): omega-conotoxin-GVIA (0.5 mM), omega-agatoxin-IVA (0.1 mM). 2-aminoethoxydiphenylborane (2APB; 10 $\mathrm{mM}$ in ethanol or $100 \mathrm{mM}$ in DMSO, $-20^{\circ} \mathrm{C}$ ) was kindly provided by Dr. Mikoshiba (Brain Science Institute, RIKEN, Japan). Efonidipine and its enantiomers were kindly provided by Nissan Chemical Industries, Ltd (Tokyo, Japan).

For the preparation of carbachol for application to the chamber, a volume of the $1 \mathrm{M}$ stock was applied to the perfusing solution (before entering the line tube) to create the desired concentration. The time of application was defined as the time at which the carbachol-containing solution began to perfuse the recording chamber (approximately $2 \mathrm{~min}$ after carbachol addition to the perfusing solution). With the chamber volume of 3 $\mathrm{ml}$, and a perfusion rate of $2 \mathrm{ml} / \mathrm{min}$, the concentration in the chamber was estimated to be around $100 \mu \mathrm{M}$ at $1 \mathrm{~min}$ after the start of $200 \mu \mathrm{M}$ carbachol application.

A slow perfusion rate $(0.2 \mathrm{ml} / \mathrm{min})$ was used for later experiments to minimize costly reagent use. In these experiments, carbachol was directly applied into the chamber by a pipette. They are noted as 'direct bath application of carbachol' in Results. A gravity-flow setup was used to maintain the slow perfusion rate. The bath volume was estimated to be 2.5 $\mathrm{ml}$ (though it varied from 2 to $3 \mathrm{ml}$ by perfusion and vacuuming conditions) Carbachol concentrates of $7.5 \mu 1$ (100 mM in water) were mixed with $30 \mu 1$ of the standard solution (to enhance diffusion in the bath) and gently bath-applied with a pipette, resulting in a bath carbachol concentration of $300 \mu \mathrm{M}$.

\section{Study design and analysis}

Most experimental manipulations were assigned either randomly, by throwing dice, or alternating experimental versus control conditions.

To assess changes in the mIPSC frequency, four consecutive time windows of three minutes each were introduced to each cell's recording. These were defined as: base, 0-3 $\mathrm{min}, 3-6 \mathrm{~min}, 6-9 \mathrm{~min}$. Carbachol application began just after the base time window. In each cell, frequency values (in $\mathrm{Hz}$ ) from the $0-3,3-6,6-9 \mathrm{~min}$ time windows were subtracted by the frequency value of base time window, which were defined as frequency change values. The frequency change values from the experimental cell groups and the control cell groups were each pooled (cell number $[\mathrm{n}] \times 3$ values for each group) and analysed by Mann-Whitney's U-test (U-test) for statistical difference $(P<0.05$ was considered significant). The values are expressed as mean $\pm \mathrm{SD}$.

We assessed three time windows after the carbachol application to make the analysis more specific for the detection of carbachol effects that tended to last for a long duration. Increases in the current frequency can be caused by occasional transient bursts (Fig. 1 $\mathrm{Cb}$, upper) unrelated to the carbachol effects. If only one time window after carbachol was assessed to count the number of events, we would not be able to differentiate between transient spontaneous bursts unrelated to carbachol and a modest but long-lasting frequency increase in response to carbachol (Fig. $1 \mathrm{Ca}$, middle). The introduction of three time windows to a cell enables us to confine a transient burst to one time window and get only one value of increased frequency out of the cell's three values. On the other hand, we can reliably identify a long-lasting response that was specific to the carbachol action, and get three values of increased frequency out of the cell's three values. Thus, the introduction of three time windows raises the specificity of the analysis.

\section{Puff application of GABA}

GABA $(30 \mu \mathrm{M})$ dissolved in the perfusing solution was puff applied (2-5 psi, $50-500 \mathrm{~ms}$ at $30 \mathrm{~s}$ intervals) via a glass pipettes which was made similarly to that used for whole cell recording (Picospritzer II, General Valve Corporation, Fairfield, NJ, USA: for electronic pulse generation; SEN7203, Nihonkoden, Tokyo, Japan). Because mIPSCs often contaminate puff current peak values, the mean values of the puff currents were assessed. The puff current was calculated as follows: the averaged current trace of an $850 \mathrm{~ms}$ time window beginning $100 \mathrm{~ms}$ after the start of the puff, minus a baseline value consisting of the averaged current trace of an $850 \mathrm{~ms}$ time window up to $50 \mathrm{~ms}$ before the start of puff (thus positive values are obtained for the puff current, see Fig. 3Ab). For each cell, means of the puff current amplitudes were calculated for the base, $0-3,3-6$, and 6-9 min time windows (one puff at $30 \mathrm{~s}$ intervals resulted in 6 amplitude values per $3 \mathrm{~min}$ time window). Ratios relative to the base values were calculated for the $0-3$, 3-6, and 6-9 min time windows and these ratios were defined as amplitude change ratios. The amplitude change ratio values for the carbachol-exposed and control groups were expressed as mean $\pm \mathrm{SD}$.

\section{Assessment of peaks in the mIPSC amplitude distribution}

We applied a method used by Edwards et al. (1990; Asertine's analysis) to diagnose the occurrence of peaks in mIPSC amplitude histograms. The autocorrelation function (ACF) of the amplitude histograms was calculated using the expression: $\mathrm{ACF}(\mathrm{j})=\left\{\Sigma_{\mathrm{i}} \mathrm{H}(\mathrm{i}) \mathrm{H}(\mathrm{i}+\mathrm{j})\right\} /\left(\Sigma_{\mathrm{i}} \mathrm{H}(\mathrm{i}) \mathrm{H}(\mathrm{i})\right)$, where $\mathrm{H}(\mathrm{i})$ is the height of the $i^{\text {th }}$ bin which is centred at the amplitude value given by $i \times$ bin width. The ACFs were compared with a smoothed autocorrelation function in which each point was replaced by a five-point rolling average. The two functions were superimposed, and if the ACF showed at least two consecutive and equally spaced peaks and dips, the amplitudes were diagnosed as quantally distributed.

\section{Acknowledgements}

We thank Dr. T. Hori (Okinawa institute of Science and Technology) for providing instructions on patch clamp and puff application methods; Dr. K. Kato (Kochi Medical School) for advice on slice preparation and providing 
D-AP5; Dr. GZ Huang (Northwestern Univ. Chicago. USA) for providing instruction on slice preparation; Dr. M. Taniguchi (Kochi Medical School) for assistance in setting up experimental apparatuses and animal care, and for troubleshooting; Dr. K. Mikoshiba (Brain Science Institute, RIKEN) for providing 2-APB, and Dr. A. Yamamoto (Nissan Chemical Industries, Ltd.) for providing efonidipine and enantiomers. This work was supported in part by research grants from the Ministry of Education, Culture, Sports, Science and Technology of Japan and from Kochi University.

\section{References}

. Araneda, R., Firestein, S., 2006. Adrenergic enhancement of inhibitory transmission in the accessory olfactory bulb. J Neurosci. 26, $3292-8$.
Biervert, C., Schroeder, B., Kubisch, C., Berkovic, S., Propping, P., Jentsch, T., Steinlein, O., 1998. A potassium channel
mutation in neonatal human epilepsy. Science. $279,403-6$.

mutation in neonatal human epilepsy. Science. $279,403-6$.
Binns, K., Brennan, P., 2005. Changes in electrophysiological activity in the accessory olfactory bulb and medial amygdala associated with mate recognition in mice. Eur J Neurosci. $21,2529-37$.
Brennan, P., Keverne, E., 1989. Impairment of olfactory memory by local infusions of non-selective excitatory amino acid receptor antagonists into the accessory olfactory bulb. Neuroscience. $33,463-8$.
Buckley, N., Bonner, T., Brann, M., 1988. Localization of a family of muscarinic receptor mRNAs in rat brain. J Buckley, N., Bonner, T., Brann, M., 1988. Localization of a family or muscarinic receptor mRe. 8, 4646-52.
Carson, K., Burd, G., 1980. Localization of acetylcholinesterase in the main and accessory olfactory bulbs of the mouse Carson, K., Burd, G., 1980. Localization of acetylcholinesterase in the main and accessory olfactory bulbs of the mot
by light and electron microscopic histochemistry. J Comp Neurol. 191, 353-71.
Castillo, P., Carleton, A., Vincent, J., Lledo, P., 1999. Multiple and opposing roles of cholinergic transmission in the Castillo, P., Carleton, A., Vincent, J., Lledo, P., 1999. Multiple and opposing roles of cholinergic transmission in the
main offactory bulb. J Neurosci. $19,9180-91$.
Castro, J., Hovis, K., Urban, N., 2007. Recurrent dendrodendritic inhibition of accessory olfactory bulb mitral cells Castro, J., Hovis, K., Urban, N., 2007. Recurrent dendrodendritic inhibition of accessory olfactory bulb mitral cells
requires activation of group I metabotropic glutamate receptors. J Neurosci. 27, 5664-71. receptors. Pharmacol Rev. 50, 279-90.
Constantion de Olmos, J., Hardy, H., Heimer, L., 1978. The afferent connections of the main and the accessory olfactory bulb formations in the rat: an experimental HRP-study. J Comp Neurol. 181, 213-44.
Delmas, P., Brown, D., 2002. Junctional signaling microdomains: bridging the gap between the neuronal cell surface and Ca2+ stores. Newron shingling

Delmas, P., Brown, D., 2005. Pathways modulating neural KCNQ/M (Kv7) potassium channels. Nat Rev Neurosci. 6, Djurisic, M., Popovic, M., Carnevale, N., Zecevic, D., 2008. Functional structure of the mitral cell dendritic tuft in the rat
olfactory bulb. J Neurosci. 28, 4057-68.

Dost, R., Rundfeldt, C., 2000. The anticonvulsant retigabine potently suppresses epileptiform discharges in the low $\mathrm{Ca}++$ and low $\mathrm{Mg}++$ model in the hippocampal slice preparation. Epilepsy Res. 38, 53-66.

Edwards, F., Konnerth, A., Sakmann, B., 1990. Quantal analysis of inhibitory synaptic transmission in the dentate gyrus of rat hippocampal slices: a patch-clamp study. J Physiol. 430, 213-49.

Elmedyb, P., Calloe, K., Schmitt, N., Hansen, R., Grunnet, M., O Foehring, R., Mermelstein, P S Song W W Ulich, S, Surmeier, D neocortical and neostriatal neurons. J Neurophysiol. 84, 2225-36.

Furey, M., Pietrini, P., Haxby, J., 2000. Cholinergic enhancement and increased selectivity of perceptual processing

during working memory. Science. 290, 2315-9.
Furukawa, T., Miura, R., Honda, M., Kamiya, N., Mori, Y., Takeshita, S., Isshiki, T., Nukada, T., 2004. Identification of $\mathrm{R}(-)$-isomer of efonidipine as a selective blocker of T-type Ca2+ channels. Br J Pharmacol. 143,

Ghatpande, A., Sivaraaman, K., Vijayaraghavan, S., 2006. Store calciu

rat main olfactory bulb. Jeeurophysiol. $95,1345-55$.
Ghatpande, A., Gelperin, A., 2009. Presynaptic muscarinic receptors enhance glutamate release at the mitral/tufted to

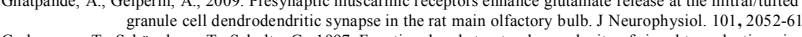

Gudermann, T., Schöneberg, T., Schultz, G., 1997. Functional and structural complexity of signal transduction via G-protein-coupled receptors. Annu Rev Neurosci. 20, 399-427.

Hendrickson, R., Krauthamer, S., Essenberg, J., Holy, T., 2008. Inhibition shapes sex selectivity in the mouse accessory

Jia, C., Chen, W., Shepherd, G. 1999. Synaptic orgaizition.

W., Shepherd, G., 1999. Synaptic organization and neurotransmitters in the rat accessory olfactory bulb.

Kaba, H., Keverne, E., 1988 . The effect of microinfusions of drugs into the accessory olfactory bulb on the olfactory

block to pregnancy. Neuroscience. $25,1007-11$.
Kaba, H., Hayashi, Y., Higuchi, T., Nakanishi, S., 1994. Induction of an olfactory memory by the activation of a metabotropic glutamate receptor. Science. 265, 262-4.

Kasamatsu, T., 1991. Adrenergic regulation of visuocortical plasticity: a role of the locus coeruleus system. Prog Brain Res. 88, 599-616.

Keverne, E., de la Riva, C., 1982. Pheromones in mice: reciprocal interaction between the nose and brain. Nature. 296,

148-50.
Lechner, S., Mayer, M., Boehm, S., 2003. Activation of M1 muscarinic receptors triggers transmitter release from rat
sympathetic neurons through an inhibition of M-type K+ channels. J Physiol. 553, 789-802.

sympathetic neurons through an inhibition of M-type K+ channels. J Physiol. 553, 789-802.
Leinders-Zufall, T., Brennan, P., Widmayer, P., S, P., Maul-Pavicic, A., Jäger, M., Li, X., Breer, H., Zufall, F., Boehm, T., 2004. MHC class I peptides as chemosensory signals in the vomeronasal organ. Science. 306, 1033-7.

Luo, M., Fee, M., Katz, L., 2003. Encoding pheromonal signals in the accessory olfactory bulb of behaving mice. Science.

Macrides, F., Davis, B., Youngs, W., Nadi, N., Margolis, F., 1981. Cholinergic and catecholaminergic afferents to the Neurol. 203, 495-514

Martire, M., Castaldo, P., D'Amico, M., Preziosi, P., Annunziato, L., Taglialatela, M., 2004. M channels containing KCNQ2 subunits modulate norepinephrine, aspartate, and GABA release from hippocampal nerve

terminals. J Neurosci. 24, 592-7.
Maruyama, T., Kanaji, T., Nakade, S., Kanno, T., Mikoshiba, K., 1997. 2APB, 2-aminoethoxydiphenyl borate, a

membrane-penetrable modulator of Ins(1,4,5)P3-induced Ca2+ release. J Biochem. 122, 498-505.
Matsuoka, M., Kaba, H., Moriya, K., Yoshida-Matsuoka, J., Costanzo, R., Norita, M., Ichikawa, M., 2004 Remodelin of reciprocal synapses associated with persistence of long-term memory. Eur J Neurosci. 19, 1668-72.

of reciprocal synapses associated with persistence of long-term memory. Eur J Neurosci. 19, 1668-72.
Meisami, E., Mikhail, L., Baim, D., Bhatnagar, K., 1998. Human olfactory bulb: aging of glomeruli and mitral cells and a
search for the accessory offactory bulb. Ann N Y Acad Sci. 855, 708-15.
Miledi R., 1966. Strontium as a substitute for calcium in the process of transmitter release at the neuromuscular junction.

Meisami, E., Mikhail, L, Baim, D., Bhatnagar, K., 1998. Human olfactory bulb: aging of glomeruli and mitral cells and a
search for the accessory olfactory bull. Ann N Y Acad Sci. 85, 708 -15.
Miledi R., 1966. Strontium as a substitute for calcium in the process of transmitter release at the neuromuscular junction.

Miledi R., 1966. Strontium as a substitute
Nature $212,1173-1282$

Nature 212, 1173-1282.
Mori, K., 1987. Membrane and synaptic properties of identified neurons in the olfactory bulb. Prog Neurobiol. 29, Ojima, H., Yamasaki, T., Kojima, H., Akashi, A., 1988. Cholinergic innervation of the main and the accessory olfactory bulbs of the rat as $\mathrm{r}$ (Berl). $178,481-8$.
.

Otto, J., Kimball, M., Wilcox, K., 2002. Effects of the anticonvulsant retigabine on cultured cortical neurons: changes in electroresponsive properties and synaptic transmission. Mol Pharmacol. 61, 921-7.

Peretz, A., Degani, N., Nachman, R., Uziyel, Y., Gibor, G., Shabat, D., Attali, B., 2005. Meclofenamic acid and diclofenac, novel templates of $\mathrm{KCNQ} / \mathrm{Q} 3$ potassium channel openers, depress cortical neuron activity

and exhibit anticonvulsant properties. Mol Pharmacol. 67, 1053-66.
Peretz, A., Sheinin, A., Yue, C., Degani-Katzav, N., Gibor, G., Nachman, R., Gopin, A., Tam, E., Shabat, D., Yaari, Y., Attali, B., 2007. Pre- and postsynaptic activation of M-cha
firing and transmitter release. J Neurophysiol. $97,283-95$.

Perez-Reyes, E., Van Deusen, A., Vitko, I., 2009. Molecular pharmacology of human Cav3.2 T-type Ca2+ channels: block by antihypertensives, antiarrhythmics, and their analogs. J Pharmacol Exp Ther. 328, $621-7$.

block by antihypertensives, antiarrhythmics, and their analogs. J Pharmacol Exp Ther. 328, $621-7$.
Randall, A., Tsien, R., 1997. Contrasting biophysical and pharmacological properties of T-type and R-type calcium

channels. Neuropharmacology. 36, 879-93.
Rosser, A., Keverne, E., 1985 . The importance of central noradrenergic neurones in the formation of an olfactory memory in the prevention of pregnancy block. Neuroscience. 15, 1141-7.

Rundfeldt, C., Netzer, R., 2000. Investigations into the mechanism of action of the new anticonvulsant retigabine. Interaction with GABAergic and glutamatergic neurotransmission and with voltage gated ion channels. Arzneimittelforschung. 50, 1063-70.

Sakaba, T., 2008. Two $\mathrm{Ca}(2+)$-dependent steps controlling synaptic vesicle fusion and replenishment at the cerebellar

Silver, R., Lubke, J., Sakmann, B., Feldmeyer, D., 2003. High-probability uniquantal transmission at excitatory synapses in barrel cortex. Science. 302, 1981-4.

Soong, T., Stea, A., Hodson, C., Dubel, S., Vincent, S., Snutch, T., 1993. Structure and functional expression of a

member of the low voltage-activated calcium channel family. Science, 260, 1133-6.
Szabadics, J., Varga, C., Molnár, G., Oláh, S., Barzó, P., Tamás, G., 2006. Excitatory effect of GABAergic axo-axonic cells in cortical microcircuits. Science. 311, 233-5.
Takahashi, T., 1990. Membrane currents in visually identified motoneurones of neonatal rat spinal cord. J Physiol. 423,

$27-46$.
Taniguchi, M., Kaba, H., 2001. Properties of reciprocal synapses in the mouse accessory olfactory bulb. Neuroscience.

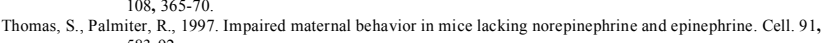
$583-92$.
Tinel, N., Lauritzen, I., Chouabe, C., Lazdunski, M., Borsotto, M., 1998. The KCNQ2 potassium channel: splice variants,
functions functional $171-6$.

Xu, F., Schaefer, M., Kida, I., Schafer, J., Liu, N., Rothman, D., Hyder, F., Restrepo, D., Shepherd, G., 2005 Simultaneous activation of mouse main and accessory olfactory bulbs by odors or pheromones. J Comp Neurol. 489, 491-500.

Zhang, H., Chen, S., Cai, Y., Richardson, T., Driver, L., Lopez-Berestein, G., Pan, H., 2009. Signaling mechanisms mediating muscarinic enhanc
Neuroscience. $158,1577-88$. 
Figure Legends

FIG. 1. Carbachol increased the frequency of spontaneous mIPSCs. A, Spontaneous currents reversed polarity around $0 \mathrm{mV}$, the chloride equilibrium potential. B, Spontaneous currents were abolished within $5 \mathrm{~min}$ by bath application of the GABA blocker, bicuculline $(20 \mu \mathrm{M}) . \mathrm{Ca}$, Examples of recordings with carbachol application. Uppermost trace: typical response to carbachol. Middle: delayed response. Lower: a modest response and rundown. $\mathrm{Cb}$, Examples with vehicle application. Upper: transient spontaneous bursts at the final part of the recording. Middle: run down. Lower: stable. The scale bar is for both $\mathrm{Ca}$ and $\mathrm{Cb}$. The angled arrows in $\mathrm{Ca}$ and $\mathrm{Cb}$ show the times at which carbachol or placebo application started. Cc, An inter-event interval cumulative plots of $\mathrm{Ca}$ uppermost trace. In this cell, the frequency increases in all three $3 \mathrm{~min}$ time windows after carbachol application ( 3 curves are indistinguishable in the plot, left side curve) were significant compared with the frequency before carbachol (base, right side curve) by Kolmogorov-Smirnov test. The numbers in the parentheses are the mean frequencies of each time window. $\mathrm{D}$, Distributions of mIPSC frequencies in 3 min time window before and in 3 min time window (from 3 to $6 \mathrm{~min}$ ) after carbachol or vehicle application. The distribution of mIPSC frequencies after carbachol application was skewed and was not Gaussian. E, The U-test showed a significant increase in mIPSC frequency in the carbachol application group compared with the vehicle application group. F, A giant spontaneous current (arrow) of unidentified origin. Such currents were seen in the presence of TTX $1 \mu \mathrm{M}$. They were rare, but were more frequently seen in thick slices $(500 \mu \mathrm{m})$.

FIG. 2. Carbachol enhanced the amplitudes of the mIPSCs in some cells. A, Amplitude change ratios after carbachol or vehicle applications (any time window's amplitude/base time window's amplitude); b, base time window, $0-3$, the time window from 0 to 3 min after the application, etc. B, Upper: pie charts summarize the observed shifts in the amplitude cumulative plot curves. For each cell (carbachol application, $\mathrm{n}=10$; control, $\mathrm{n}=6$ ), 3 curves for the 3 time windows were analysed. A rightward shift indicates an increase in amplitude, while a leftward shift, a decrease. Note that the rightward shifts are only observed in the carbachol-applied group. Lower: example cell amplitude cumulative plots from each pie chart category (arrow) demonstrating the shifts summarized in the chart. C, Absence of correlations among frequency change value and amplitude change ratio. This implies the amplitude change is not dependent on presynaptic calcium availability. Values from each time window were plotted as a point (n [cell number] $\times 3$ [time windows from each cell] $=63$ points $)$, Correl: coefficient value.

FIG. 3. Carbachol did not change the mitral cell's sensitivity to GABA. Aa, GABA puffs onto a recorded mitral cell evoked currents that reversed around $0 \mathrm{mV}$, indicating that the currents were carried by chloride. Ab, The puff current value was calculated from the mean values in $850 \mathrm{~ms}$ time windows before and after the puff. B, Summary of puff current amplitudes before (base) and after carbachol or vehicle application (0-3, 3-6, 6-9 $\mathrm{min}$ ). No significant changes in amplitude were observed. The means of amplitudes after the applications are shown by the ratios to the base amplitudes. Error bars represent SDs. See Results for detailed values. C, An example of a cell from the carbachol-applied group. The background mIPSC frequency increased independently of increases in the puff current. Arrows indicate the times of recordings $(* 1, * 2)$ which are shown below.

FIG. 4. The carbachol effect was mediated by M1 receptors. A, Muscarinic agonist pilocarpine increased the current frequency while muscarinic antagonist scopolamine blocked the carbachol effect. Pirenzepine (M1 + M4 antagonist) blocked the carbachol effect. On the right side of the bar pairs are $P$ values by U-test. Sidebars are $\pm 1 \mathrm{SD}$ ranges. See results for further details. B, The carbachol effect was apparent in the presence of himbacine (M2 + M4 antagonist) or 4-DAMP (M3 antagonist).

FIG. 5. Carbachol could increase the mIPSC frequency without effect on glutamate release from mitral cells. A, Schematic drawing of the dendrodendritic synapse in the accessory olfactory bulb. Glutamatergic and GABAergic synapses reside in close proximity. When a mitral cell releases glutamate, the granule cell depolarizes and releases GABA back onto the mitral cell. B, Carbachol effect remained in the presence of mixtures of ionotropic and metabotropic glutamatergic receptor antagonists. On the right side of the bar pairs are $P$ values by U-test. Sidebars are $\pm 1 \mathrm{SD}$ ranges. See results for further details. C, Cells frequently showed robust increases in the mIPSC frequency when the holding potential was raised from $-70 \mathrm{mV}$ to $+30 \mathrm{mV}$ (left). The recorded cell likely releases glutamate as a result of depolarization and stimulates granule cells to release GABA reciprocally. In the presence of mixed glutamatergic blockers, the frequency increase by mitral cell depolarisation was never observed (right, with $5 \mathrm{mM}$ kynurenic acid $+200 \mu \mathrm{M}$ AP3 $+50 \mu \mathrm{M}$ CNQX $+50 \mu \mathrm{M}$ D-AP5). D, Bath application of glutamic acid $(100 \mu \mathrm{M})$ caused a robust increase in the mIPSC frequency. Kynurenic acid + AP3 blocked the action (not shown). An arrow indicates the time of the direct bath application.

FIG. 6. A, Antagonists of L- or T-type calcium channels or intracellular calcium had no significant effect on the carbachol's action. B, Actions of calcium channel blockers on mIPSCs. Sensitivity to a low concentration of $\mathrm{Ni}$ suggests the involvement of $\mathrm{T}$ or R-type channels. An insensitivity to nimodipine and to the highly specific T-type blocker (-)-efonidipine excludes the involvement of T-type channels. P-, Q-, and N-type channels were also excluded as the calcium source for the recorded events. Straight arrows indicate the time of direct bath application of the drug concentrate by a pipette. Abbreviations: $\mathrm{Ni}$, nickel chloride; $\mathrm{Cd}$, cadmium chloride; $\mathrm{Co}$, cobalt chloride; (-)Efo, R(-) enatiomer of efonidipine; Nimo, nimodipine; AgaIV, omega-agatoxin-IVA; ConoVI, omega-conotoxin-GVIA. C, Summary of the actions of calcium channel blockers (in $\mu \mathrm{M}$ ) on mIPSC. The profile of inhibition by calcium channel blockers suggests a dominant role of R-type calcium channel underlying the mIPSC activity.

FIG. 7. A, Barium caused a robust increase in the mIPSC frequency. This suggests the involvement, in the AOB, of KCNQ channels which, when closed by barium, allow the depolarization of granule cells. The KCNQ channel-specific antagonist XE-991 also increased the mIPSCs (glutamatergic blockers present). Barium or XE-991 increased mIPSCs regardless of the presence or absence of glutamate receptor antagonists. B, KCNQ channel openers blocked the carbachol effect. On the right side of the bar pairs are $P$ values by U-test. Sidebars are \pm 1 SD ranges. See results for further details.

FIG. 8. Synchronized multiple quantum currents compose the mIPSCs. A, Examples of notched currents, which indicate the summation of quanta currents. B, Amplitude distribution showed some peaks at regular intervals. $\mathrm{C}$, Asertine analysis of $\mathrm{B}$. The analysis reveals the amplitude peaks to be at regular intervals. A line represents the autocorrelation function (ACF) of the simulated data shown in panel A. The curve of a dotted line represents the 'smoothed' ACF, i.e. the curve created by averaging each point of the original $\mathrm{ACF}$ and the two points on either side of it. Note that the original $\mathrm{ACF}$ crosses the smoothed ACF at somewhat regular intervals.

\section{Supplementary Figure Legend}

FIGURE The profile of inhibition by calcium channel blockers. Straight arrows indicate the time of direct bath application of the drug concentrate by a pipette. A modest sensitivity of the currents to high-dose T-type blockers, was observed probably due to their non-specific actions. Insensitivity to D-AP5 excluded NMDA channels as the calcium source for the recorded events. Abbreviations: Ami, amiloride; Mib, mibefradil; Nif, nifedipine; (+/-)Efo, racemic mixture of efonidipine; Nimo, nimodipine; AgaIV; omega-agatoxin-IVA; ConoVI, omega-conotoxin-GVIA; SNX, SNX-482 (tarantula spider venom peptide, R-type selective antagonist). 
Supplements

Supplementary Results

Unsuccessful attempts to block carbachol actions by calcium channel blockers

The L-type calcium channel blocker nifedipine, and the T-type blocker amiloride, or nickel chloride $(100 \mu \mathrm{M})$ all failed to significantly reduce carbachol's action ( $30 \mu \mathrm{M}$ nifedipine, $\mathrm{n}=10$, vehicle ethanol only, $\mathrm{n}=8$; $1 \mathrm{mM}$ carbachol application in both groups, frequencies increased by $0.5 \pm$ 0.9 vs. $0.5 \pm 1.5 \mathrm{~Hz}, P=0.29$, U-test $)(500 \mu \mathrm{M}$ amiloride, $\mathrm{n}=4$, vehicle only, $\mathrm{n}=4 ; 1 \mathrm{mM}$ carbachol application in both groups frequencies increased by $0.2 \pm 0.2$ vs. $0.4 \pm 0.6 \mathrm{~Hz}, P=0.75$, U-test $)(100 \mu \mathrm{M} \mathrm{Ni}, \mathrm{n}=$ 12 , control, $\mathrm{n}=5 ; 200 \mu \mathrm{M}$ carbachol application in both groups frequencies increased by $0.0 \pm 0.5$ vs. $0.0 \pm 0.8 \mathrm{~Hz}, P=0.84$, U-test)

Also, when the calcium channels were non-specifically blocked (probably partially because mIPSC activity should disappear [that was not the case] if calcium channels were completely blocked), by lowering the calcium concentration $(0.1 \mathrm{mM})$ and increasing magnesium $(3.6 \mathrm{mM})$ in the external solution, robust increases in the mIPSC frequency by $200 \mu \mathrm{M}$ carbachol application were still observed $(\mathrm{n}=12$, uncontrolled, frequency increased by $-0.1 \pm 0.5 \mathrm{~Hz}$ ).

\section{Actions of calcium channel blockers on mIPSCs (see Supplementary figure)}

The T-type channel blockers amiloride $(1 \mathrm{mM})$ or mibefradil $(30$ $\mu \mathrm{M}$ ) had a modest effect, though the concentrations required for the effect were higher than their T-type selective range (Suppl. figure; Randall and Tsien, 1997; Soong et al., 1993; Viana et al., 1997). The L and T-type blockers, nifedipine $(30 \mu \mathrm{M}, \mathrm{n}=6)$ or nimodipine $(30 \mu \mathrm{M}, \mathrm{n}=5)$, were not inhibitory upon the mIPSCs while the efonidipine racemic mixture $(30 \mu \mathrm{M}$, saturated, $n=4$; Perez-Reyes et al., 2009; Furukawa et al., 2004) had a modest effect. SNX-482 $(1 \mu \mathrm{M})$, a peptide that inhibits R-type currents in certain brain regions (Wilson et al., 2000), also failed to show any notable effect. Another possible calcium entry site, the NMDA channel, was ruled out using D-AP5 $(50 \mu \mathrm{M})$, which failed to inhibit mIPSCs.

\section{Inhibition of intracellurar pathways such as PLC or inositol 1,4,5-trisphosphate $\left(\mathrm{IP}_{3}\right)$ receptors did not abolish the carbachol effect}

Subtype M1, M3, and M5 muscarinic receptors up-regulate phospholipase C (PLC) activity while M2 and M4 down-regulate adenylate cyclase (AC) activity (Caulfield and Birdsall, 1998). The effectiveness of pirenzepine upon the actions of carbachol suggests an involvement of the M1 receptor, which signals via PLC. We therefore studied the influence of PLC pathway blockade upon the carbachol effect. At $15 \mu \mathrm{M}, 2$-APB blocks $\mathrm{IP}_{3}$ receptors of the endoplasmic reticulum (ER) and $\mathrm{IP}_{3}$-mediated calcium release from ER stores (Maruyama et al., 1997). A higher concentration (75 $\mu \mathrm{M})$ also blocks some store-operated calcium channels and some TRP channels. No significant differences in the carbachol effect were shown in the presence of 2 -APB at 15,75 or $150 \mu \mathrm{M}(>20 \mathrm{~min})$ compared with its vehicle ethanol or DMSO $(15 \mu \mathrm{M} 2-\mathrm{APB}, \mathrm{n}=7$, vehicle ethanol only, $\mathrm{n}=$ $4 ; 1 \mathrm{mM}$ carbachol application in both groups, frequencies increased by 0.7 \pm 1.7 vs. $-0.3 \pm 1.5 \mathrm{~Hz}, P=0.10$, U-test $)(2$-APB $75 \mu \mathrm{M}, \mathrm{n}=10$, vehicle DMSO only, $\mathrm{n}=5 ; 200 \mu \mathrm{M}$ carbachol application in both groups, frequencies increased by $-0.5 \pm 0.8$ vs. $-0.2 \pm 0.4 \mathrm{~Hz}, P=0.18$, U-test $)(150$ $\mu \mathrm{M} 2-\mathrm{APB}, \mathrm{n}=9$, vehicle DMSO only, $\mathrm{n}=6 ; 1 \mathrm{mM}$ carbachol application in both groups, frequencies increased by $0.0 \pm 1.2$ vs. $-0.1 \pm 0.8 \mathrm{~Hz}, P=$ 0.78 , U-test). Furthermore, in the presence of gadolinium $(10 \mu \mathrm{M})$, an inhibitor of store-operated calcium channels and TRP channels (Trebak et al., 2002), carbachol had a robust effect $(n=1$, frequency increased by 0.6 $\pm 0.4 \mathrm{~Hz}$ ). Thus, intracellular calcium, calcium store-operated calcium channels, and TRP channels are not significantly involved. Application of the protein kinase $\mathrm{C}$ inhibitor, $0.5 \mu \mathrm{M}$ calphostin $(>20 \mathrm{~min}$ ) under normal fluorescent lighting condition (Bruns et al., 1991) could not abolish the carbachol effect ( $1 \mathrm{mM}$ carbachol, $\mathrm{n}=5$, vehicle water only, $\mathrm{n}=3$; frequencies increased by $2.3 \pm 1.9$ vs. $0.4 \pm 1.1 \mathrm{~Hz}, P=0.005$, U-test). In the presence of the PLC inhibitor U73122 (10 $\mu \mathrm{M},>20 \mathrm{~min})$, carbachol application significantly increased the mIPSC frequency compared with vehicle-only application ( $1 \mathrm{mM}$ carbachol, $\mathrm{n}=9$, vehicle water only, $\mathrm{n}=3$; frequencies increased by $1.1 \pm 1.1$ vs. $-0.3 \pm 0.6 \mathrm{~Hz}, P=$ 0.002 , U-test).Another PLC inhibitor, $50 \mu \mathrm{M}$ edelfosine (Horowitz et al., 2005; Wong et al., 2007), also had no significant effect on the carbachol action ( $20 \mu \mathrm{M}$ edelfosine, $\mathrm{n}=8$, vehicle water only, $\mathrm{n}=8$; frequencies increased by $-0.1 \pm 0.5$ vs. $0.2 \pm 0.7 \mathrm{~Hz}, P=0.80$, U-test $)(50 \mu \mathrm{M}$ edelfosine, $\mathrm{n}=6$, vehicle water only, $\mathrm{n}=5 ; 200 \mu \mathrm{M}$ carbachol application in both groups, frequencies increased by $1.1 \pm 2.9$ vs. $0.1 \pm 0.3 \mathrm{~Hz}, P=0.56$, U-test).

As none of the PLC pathway blockers used had any significant effect on the action of carbachol, we next examined the involvement of the adenylate cyclase (AC) pathway. In the absence of carbachol, application of the AC activator forskolin resulted in a robust increase in the mIPSC frequency $(n=4)$. This may result from activation of protein kinase A (PKA) that works to increase the size of readily releasable pools of synaptic vesicles by disassociating vesicles from the actin meshwork (Greengard et al., 1993). In the olfactory bulb, muscarinic receptors are known to up-regulate AC activity (Olianas and Onali, 1992; Onali and Olianas 1995). The AC inhibitor SQ22536, however, failed to significantly block the action of $100 \mu \mathrm{M}$ carbachol ( $100 \mu \mathrm{M}$ SQ22536, $\mathrm{n}=5$, vehicle water only, $\mathrm{n}=4$; frequencies increased by $0.2 \pm 0.5$ vs. $1 \pm 1.3 \mathrm{~Hz}, P=0.16$, U-test). To test the possibility that muscarinic receptors up-regulate both AC and PLC, a mixture of the two antagonists, SQ22536 $(300 \mu \mathrm{M})$ and edelfosine $(50 \mu \mathrm{M})$, was added to the preparation (preincubation, $100 \mu \mathrm{M} \mathrm{SQ} 22536$ and $10 \mu \mathrm{M}$ edelfosine for more than an hour). Under these conditions, carbachol still increased the mIPSC frequency significantly (direct bath application of 300 $\mu \mathrm{M}$ carbachol, $\mathrm{n}=4$, vehicle only application, $\mathrm{n}=4$; frequencies increased by $1.7 \pm 1.8$ vs. $-0.5 \pm 0.5 \mathrm{~Hz}, P=0.001$, U-test).

In the absence of carbachol, SQ22536 application (AC inhibitor), which had been expected to have the opposite effect of forskolin (AC activator), surprisingly stimulated a modest increase in the mIPSC frequency ( 5 out of 6 cells), suggesting the possibility of AC down-regulation being the mechanism underlying the carbachol action. PKA down-regulation and thus dephosphorylation may reduce KCNQ currents (Schroeder et al., 1998) thereby excite presynaptic membrane and increase GABA release. To test the possibility that muscarinic receptors down-regulate $\mathrm{AC}$ while up-regulating PLC, a mixture of $10 \mu \mathrm{M}$ himbacine (blocking M2 and M4 receptors, which monopolize the AC pathway; Caulfield and Birdsall, 1998) and $50 \mu \mathrm{M}$ edelfosine was used. Nonetheless, carbachol application significantly increased the mIPSC frequency compared with vehicle (direct bath application of $300 \mu \mathrm{M}$ carbachol, $\mathrm{n}=7$, vehicle only application, $\mathrm{n}=11$; frequencies increased by $0.3 \pm 0.8$ vs. -0.6 $\pm 0.9 \mathrm{~Hz}, P=0.008$, U-test).

An alternative pathway using cyclic ADP ribose as a messenger (Higashida et al., 1996) was next considered. This requires long $(>5 \mathrm{~h})$ incubation of slices with streptozotocin to deplete the NAD ${ }^{+}$that is the precursor of the cyclic ADP messenger. We incubated slices with streptozotocin $(5 \mathrm{mM}$ ) in addition to a PLC inhibitor (edelfosine, $10 \mu \mathrm{M}$ for $5 \mathrm{~h}$ and $50 \mu \mathrm{M}$ for $20 \mathrm{~min}$ ), without any noticeable effect on the action of carbachol (direct bath, $300 \mu \mathrm{M}$, data not shown). Longer incubation was not practical in regards to the reliability of the recordings and the health of the slice.

A high concentration of carbachol stimulates $\mathrm{G}_{\mathrm{i}}$ in addition to the $\mathrm{G}_{\mathrm{q}}$ linked to $\mathrm{M} 1$ receptors (Gudermann et al., 1997). $\mathrm{G}_{\mathrm{i}}$ activates phosphatidylinositol (PI) 3-kinase and mitogen-activated protein (MAP) kinase through Ras (Alberts et al., 2002). To test the possibility that carbachol's action is mediated by PI3 kinase, we applied its inhibitor LY294002 (50 $\mu \mathrm{M}$ effective in slice; Zhang et al., 2009) combined with the PLC inhibitor edelfosine. Carbachol application still had apparent actions under these conditions $(20 \mu \mathrm{M}$ LY294002 $+10 \mu \mathrm{M}$ edelfosine, for more than $30 \mathrm{~min}$ in the holding chamber and thereafter, $100 \mu \mathrm{M} \mathrm{LY} 294002+50$ $\mu \mathrm{M}$ edelfosine for more than $15 \mathrm{~min}$ in the recording chamber, $\mathrm{n}=9$; direct bath $300 \mu \mathrm{M}$ carbachol, frequencies increased by $1.1 \pm 1.4 \mathrm{~Hz}$ ) The carbachol effect was also apparent in the presence of $50 \mu \mathrm{M}$ PD98059 (an inhibitor of MAPK pathway; the concentration reported to be effective in slices; Kawasaki et al., 2004, Yuill et al., 2007) combined with edelfosine $(10 \mu \mathrm{M}$ PD98059 $+10 \mu \mathrm{M}$ edelfosine, for more than $50 \mathrm{~min}$ in the holding chamber and thereafter, $50 \mu \mathrm{M}$ PD $98059+50 \mu \mathrm{M}$ edelfosine for more than $15 \mathrm{~min}$ in the recording chamber, $\mathrm{n}=4$; direct bath $300 \mu \mathrm{M}$ carbachol, frequency increased by $0.0 \pm 0.7 \mathrm{~Hz}$ ).

\section{Supplementary Discussion Intracellular signalling pathway downstream of muscarinic stimulation}

We could not find a pathway downstream of muscarinic receptor stimulation. There are two possible explanations: the first possibility is that the inhibitors used did not sufficiently block the intracellular pathways to show a significant effect. However, the concentrations and durations of incubation for the PLC or AC blockers were likely sufficient, as they are effective in similar slice experiments (Herold et al., 2005; Evans et al., 2001; Woodhall et al., 2007). Though depletion of phosphatidylinositol 4,5-bisphosphate $\left(\mathrm{PIP}_{2}\right)$ by PLC is the currently acceptable mechanism of KCNQ channel closure (Delmas and Brown 2005), PLC blockades act only marginally for the M1 receptor-KCNQ channel pathway (Bofill-Cardona et al., 2000; Haley et al., 2000). The possibility of cyclic ADP involvement remains viable, since we could not implement with our slices the long incubation times required to deplete the cyclic ADP ribose completely (Higashida et al., 1996). For the second possibility, without a need of intracellular pathway, G-proteins may directly modify KCNQ channels 
(Marrion, 1997). A much potent PLC inhibitor in the future may help to further address this question.

\section{Supplementary experimental procedures}

\section{Chemicals}

If not otherwise noted, chemicals were dissolved in water or, if hydrophobic, in dimethyl sulfoxide (DMSO) at the highest concentration according to the supplier's data sheet, and stored in a $-20^{\circ} \mathrm{C}$ freezer. Chemicals (stock concentration, vehicle, and storage temperature in parenthesis) were purchased from the following sources: Biomol (Plymouth Meeting, USA), calphostin (0.5 mM in DMSO); Cayman (Ann Arbor, USA), PD98059 (50 $\mathrm{mM}$ in DMSO); Sigma (St. Louis, USA), U73122 (dissolved initially in chloroform to $10 \mathrm{mM}$, divided into $100 \mu \mathrm{l}$ aliquots, dried, and stored at $-20^{\circ} \mathrm{C}$, then resuspended at 10 or $5 \mathrm{mM}$ in DMSO and stored at $-20^{\circ} \mathrm{C}$ ); Nakarai (Kyoto, Japan), gadolinium chloride; Wako (Osaka, Japan), forskolin (10 mM in ethanol), streptozotocin (500 mM in water), LY294002 (25 mM in DMSO); Calbiochem (Plymouth Meeting, USA), SQ22536 (100 $\mathrm{mM}$ in water); Tocris (Bristol, UK), edelfosine (20 $\mathrm{mM}$ in water), (RS)- $\alpha$-methyl-4-carboxyphenylglycine (MCPG; $50 \mathrm{mM}$ in $0.1 \mathrm{~N} \mathrm{NaOH}$ ); Peptide Institute (Osaka, Japan): SNX-482 $(50 \mu \mathrm{M})$.

\section{References}

Alberts B., 2002. Molecular biology of the cell, 4th edn., Garland Science, New York, USA, pp 935-937. Bofill-Cardona, E., Vartian, N., Nanoff, C., Freissmuth, M., Boehm, S., 2000. Two different signaling mechanisms
involved in the excitation of rat sympathetic neurons by uridine nucleotides. Mol Pharmacol. 57,

Bruns, R., Miller, F., Merriman, R., Howbert, J., Heath, W., Kobayashi, E., Takahashi, I., Tamaoki, T., Nakano, H., 1991. Inhibition of protein kinase $\mathrm{C}$ by calphostin $\mathrm{C}$ is light-dependent. Biochem Biophys Res Commun. 176, $288-93$. Caulfield, M., Birdsall, N., 1998. International Union of Pharmacology. XVII. Classification of muscarinic acetylcholine
receptors. Pharmacol Rev. 50, 279-90.

Delmas, P., Brown, D., 2005. Pathways modulating neural KCNQ/M (Kv7) potassium channels. Nat Rev Neurosci. 6,

Evans, D., Jones, R., Woodhall, G., 2001. Differential actions of PKA and PKC in the regulation of glutamate release by

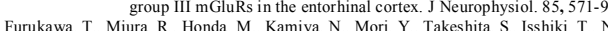
ada, T., 2004. Identification of R(-)-iso $1050-7$.

Greengard, P., Valtorta, F., Czernik, A., Benfenati, F., 1993. Synaptic vesicle phosphoproteins and regulation of synaptic function. Science. $259,780-5$.

Gudermann, T., Schöneberg, T., Schultz, G., 1997. Functional and structural complexity of signal transduction via G-protein-coupled receptors. Annu Rev Neurosci. 20, 399-427.

Haley, J., Abogadie, F, Fernandez-Fernandez, J. Dayrell, M., Vallis, Y., Buckley, N., Brown, D., 2000. Bradykinin, but not muscarinic, inhibition of $\mathrm{M}-\mathrm{c}$.
C-beta 4. J Neurosci. 20, RC105.

Herold, S., Hecker, C., Deitmer, J., Brockhaus, J., 2005. alphal-Adrenergic modulation of synaptic input to Purkinje

neurons in rat cerebellar brain slices. J Neurosci Res. $82,571-9$.
Higashida, H., Egorova, A., Hoshi, N., Noda, M., 1996. Streptozotocin, an inducer of NAD+ decrease, attenuates M-potassium current inhibition by ATP, bradykinin, angiotensin II, endothelin 1 and acetylcholine in NG108-15 cells. FEBS Lett. 379, 236-8

Horowitz, L., Hirdes, W., Suh, B., Hilgemann, D., Mackie, K., Hille, B., 2005. Phospholipase C in living cells: activation, J Gen Physiol. 126, 243-62.

Kawasaki, Y., Kohno, T., Zhuang, Z., Brenner, G., Wang, H., Van Der Meer, C., Befort, K., Woolf, C., Ji, R., 2004. Ionotropic and metabotropic receptors, protein kinase A, protein kinase C, and Src contribute to
C-fiber-induced ERK activation and cAMP response element-binding protein phosphorylation in dorsa horn neurons, leading to central sensitization. J Neurosci. 24, 8310-21.

Marrion, N., 1997. Control of M-current. Annu Rev Physiol. 59, 483-504.

Maruyama, T., Kanaji, T., Nakade, S., Kanno, T., Mikoshiba, K., 1997. 2APB, 2-aminoethoxydiphenyl borate, a membrane-penetrable modulator of Ins (1,4,5)P3-induced Ca2+ release. J Biochem. 122, 498-505.

Neurochem. 58, 1723-9.
Onali, P., Olianas, M., 1995. Bimodal regulation of cyclic AMP by muscarinic receptors. Involvement of multiple G proteins and different forms of adenylyl cyclase. Life Sci. 56, 973-80.

Perez-Reyes, E., Van Deusen, A., Vitko, I., 2009. Molecular pharmacology of human Cav3.2 T-type Ca2+ channels: block by antihypertensives, antiarrhythmics, and their analogs. J Pharmacol Exp Ther. 328, $621-7$ Randall, A., Tsien, R., 1997. Contrasting biophysical and pharmacological properties of T-type and R-type calci channels. Neuropharmacology. 36, 879-93.

Schroeder, B., Kubisch, C., Stein, V., Jentsch, T., 1998. Moderate loss of function of cyclic-AMP-modulated
KCNQ2/KCNQ3 K+ channels causes epilepsy. Nature. 396, 687-90.

Soong, T., Stea, A., Hodson, C., Dubel, S., Vincent, S., Snutch, T., 1993. Structure and functional expression of a

member of the low voltage-activated calcium channel family. Science. 260, $1133-6$.
Trebak, M., Bird, G., McKay, R., Putney, J.J., 2002. Comparison of human TRPC3 channels in receptor-activated and store-operated modes. Differential sensitivity to channel blockers suggests fundamental differences in

Viana, F., Van den Bosch, L., Missiaen, L., Vandenberghe, W., Droogmans, G., Nilius, B., Robberecht, W., 1997. Mibefradil (Ro 40-5967) blocks multiple types of voltage-gated calcium channels in cultured rat spinal

motoneurones. Cell Calcium. 22, 299-311.
Wilson, S., Toth, P., Oh, S., Gillard, S., Volsen, S., Ren, D., Philipson, L., Lee, E., Fletcher, C., Tessarollo, L., Copeland, N., Jenkins, N., Miller, R., 2000. The status of voltage-dependent calcium channels in alpha $1 \mathrm{E}$ knock-out mice. J Neurosci. 20, 8566-71.

Wong, R., Fabian, L., Forer, A., Brill, J., 2007. Phospholipase C and myosin light chain kinase inhibition define a

common step in actin regulation during cytokinesis. BMC Cell Biol. 8, 15 .
Woodhall, G., Ayman, G., Jones, R., 2007. Differential control of two forms of glutamate release by group III T., Ferri, C., Zhou, Q., Ferguson, A., 2007. Prokineticin 2 depolarizes paraventricular nucle

Yuill, E., Hoyda, T., Ferri, C., Zhou, Q., Ferguson, A., 2007. Prokineticin 2 depolarizes paraventricular nucleus
magnocellular and parvocellular neurons. Eur J Neurosici. 25, 425-34.
Zhang, H., Chen, S., Cai, Y., Richardson, T., Driver, L., Lopez-Berestein, G., Pan, H., 2009. Signaling mechanisms mediating muscarinic enhancement of GABAergic synaptic transmission in the spinal cord.
Neuroscience. $158,1577-88$. 
A

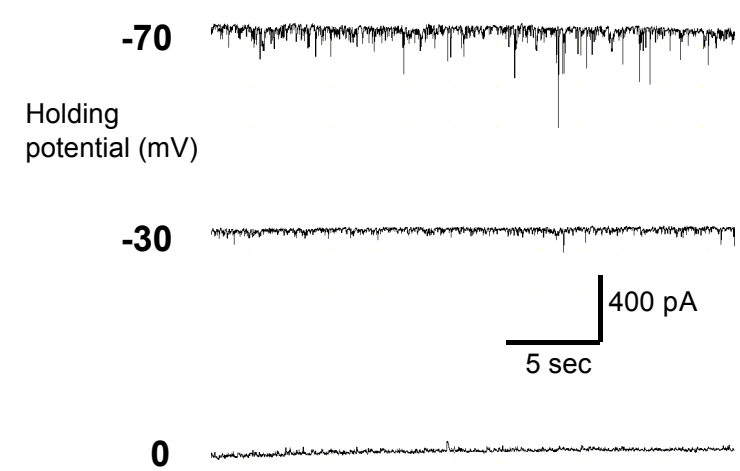

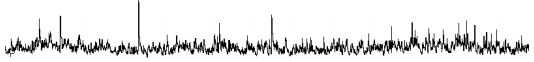

B

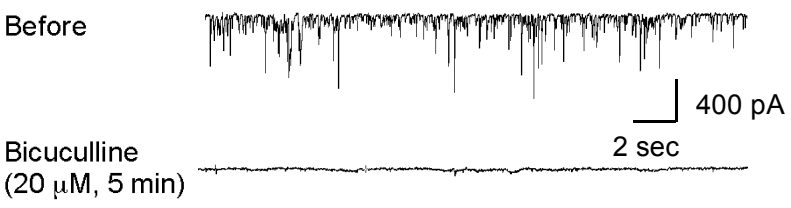

C

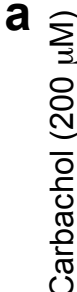

b

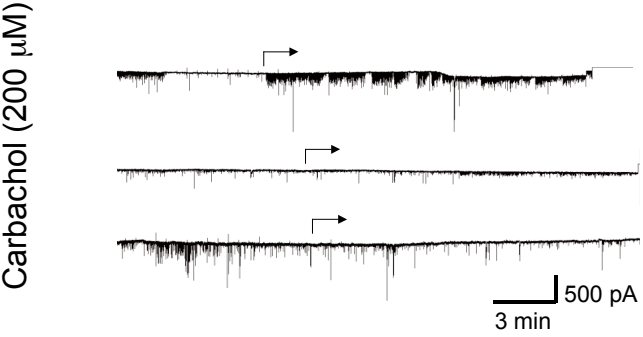

$\frac{0}{0}$
$\frac{0}{2}$
$\frac{1}{2}$
$\overline{0}$
$\frac{2}{2}$
0
0

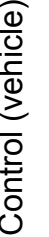

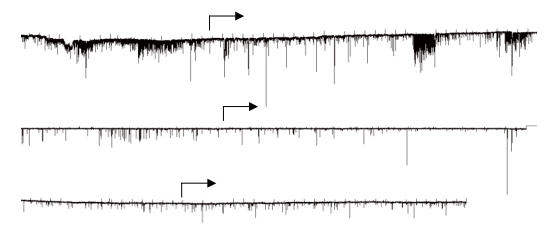

C

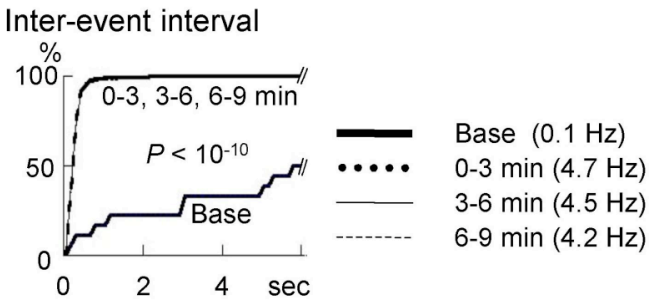

D

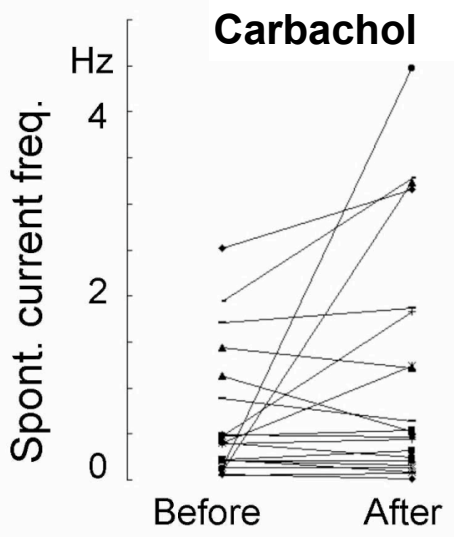

Control

E

Base condition / Application $(\mu \mathrm{M})$

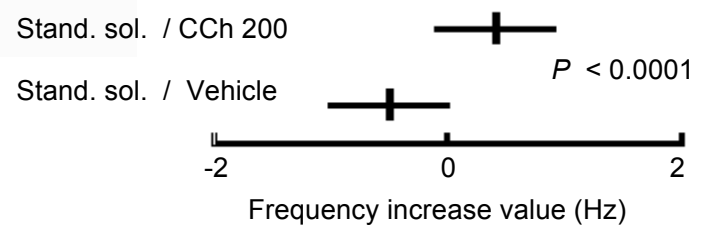

F

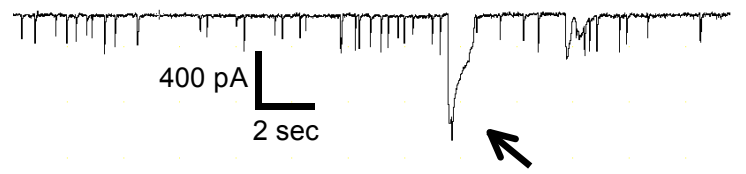

Figure 1 
A

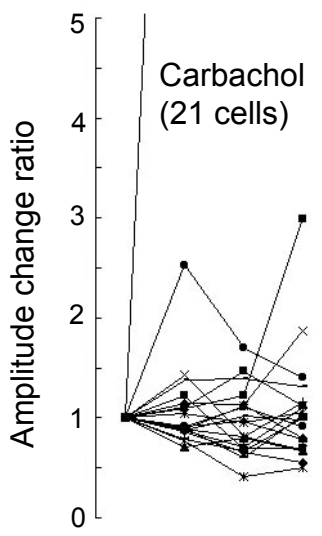

b $0-3 \quad 3-6$ 6-9

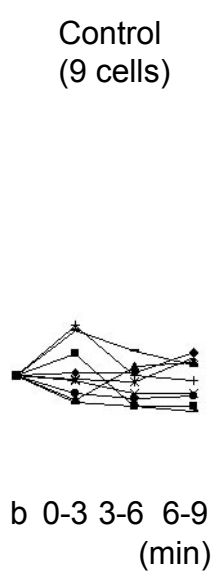

C

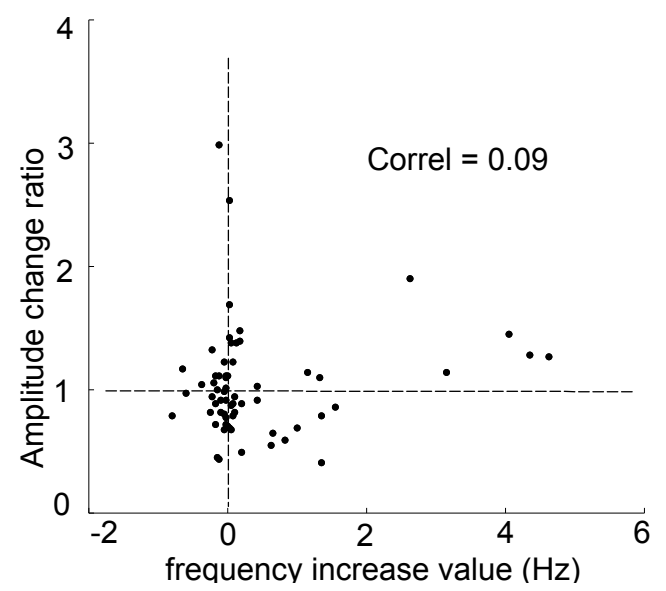

B

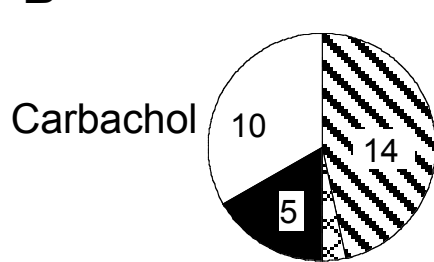

D Leftward shift

Rightward shift $\times \times$ Crossing No significant shift
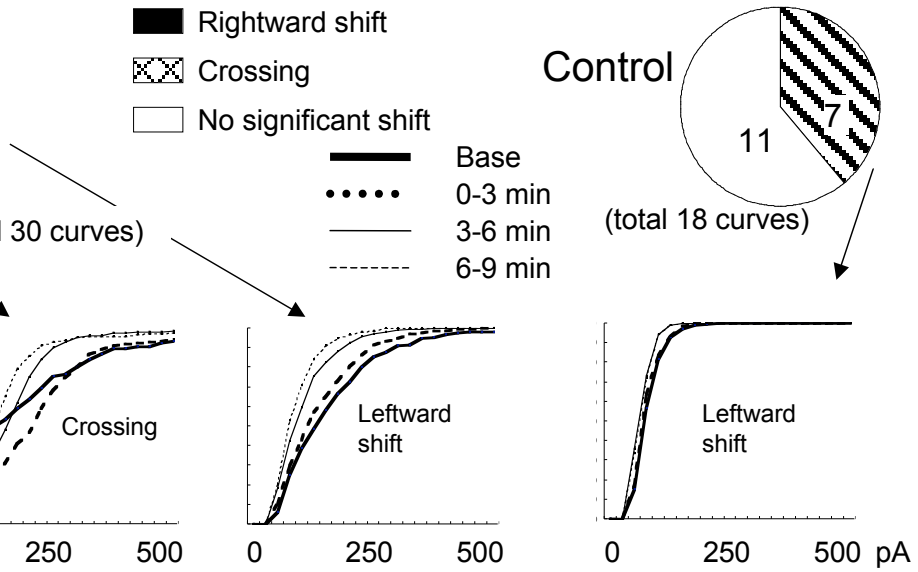

Figure 2 
A

a

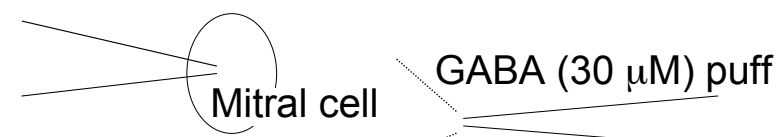

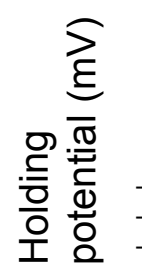

b

$$
\begin{array}{r}
\text { mean } 1 \\
\begin{array}{l}
\text { GABA puff current } \\
=\text { mean } 2-\text { mean } 1
\end{array}
\end{array}
$$

B

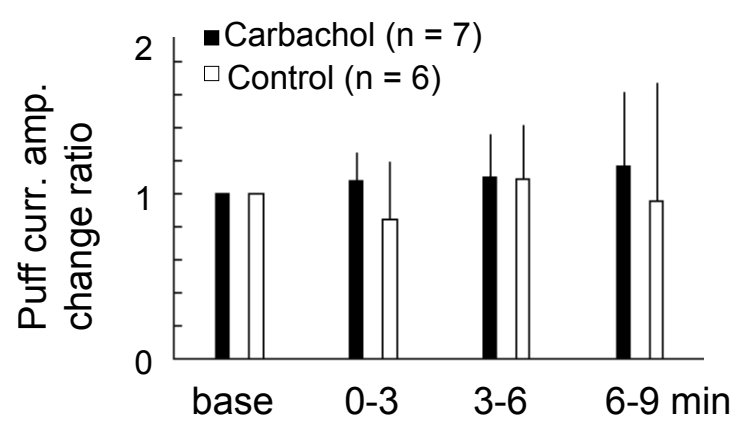

C
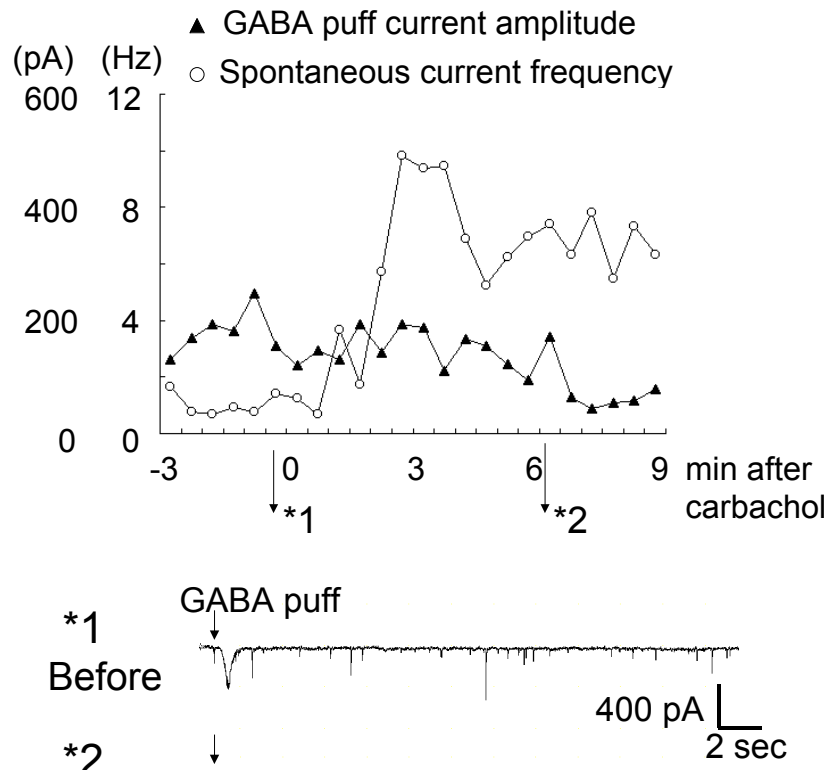

After carbachol 


\section{Figure 4}

A

\section{Base condition / Application ( $\mu \mathrm{M})$}

Stand. sol. / pilocarpine 300

Stand. sol. / Vehicle

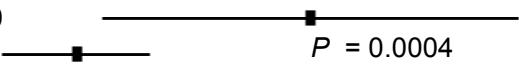

Scopolamine 100 / CCh 1mM

Vehicle / CCh $1 \mathrm{mM}$

$P=0.001$

Pirenzepine 10 / CCh 100

Vehicle / CCh 100

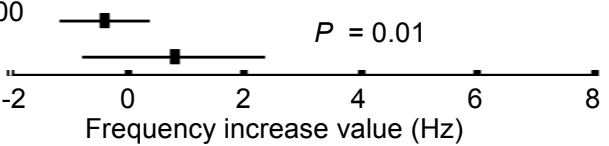

B

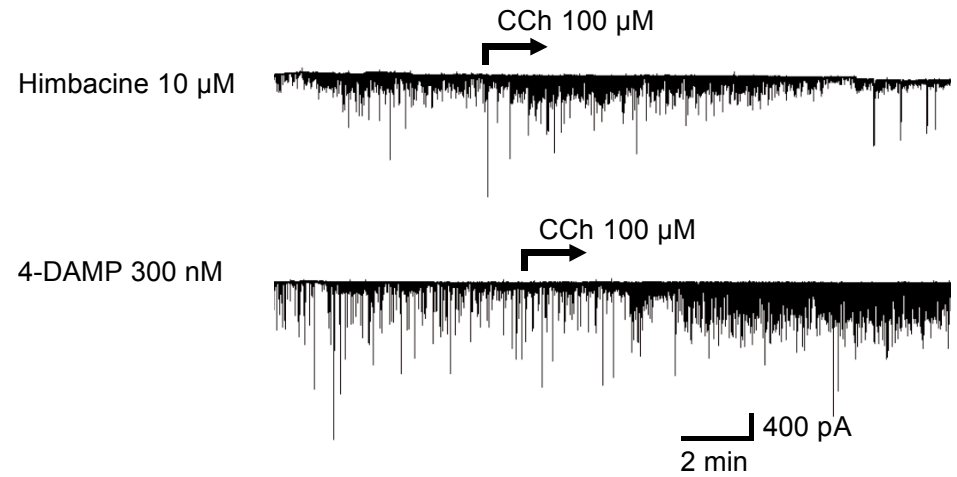


A

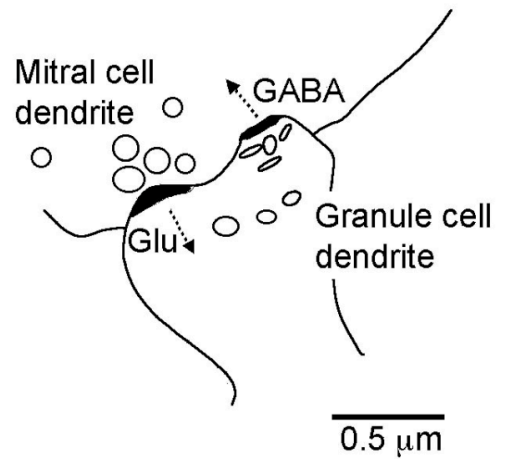

Figure 5

B

Base condition / Application $(\mu \mathrm{M})$

$\mathrm{Ky}^{*} 5 \mathrm{mM}+\mathrm{AP} 3200 / \mathrm{CCh} 1 \mathrm{mM}$

Ky* 5mM+AP3 $200 /$ Vehicle

$\longrightarrow P=0.06$

Glu. antago. mix* / CCh 300

Vehicle / CCh 300

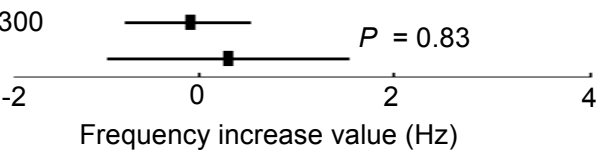

Glu. antago. mix ${ }^{\star}$

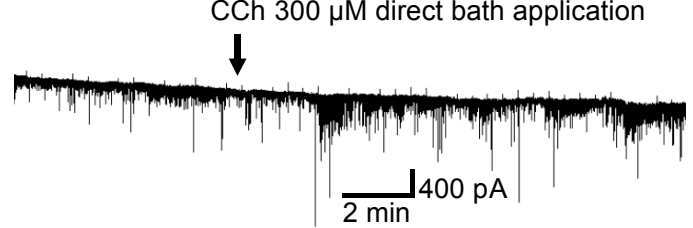

$\mathrm{Ky}^{*}$ : kynurenic acid

Glu. antago. mix* $\mathrm{Ky}^{*}(5 \mathrm{mM})+\mathrm{MCPG}(500 \mu \mathrm{M})+\mathrm{CNQX}(30 \mu \mathrm{M})+\mathrm{D}-\mathrm{AP5}(50 \mu \mathrm{M})$

C

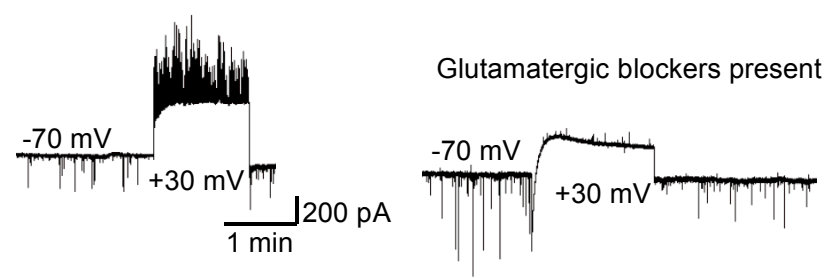

D

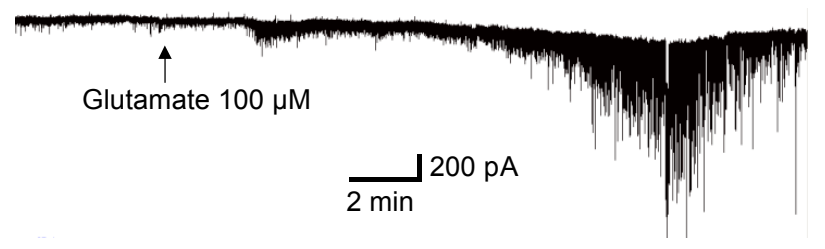


A

Base condition / Application $(\mu \mathrm{M})$

Nifedipine 30 / CCh $1 \mathrm{mM}$

Vehicle / CCh $1 \mathrm{mM}$

Mibefradil 20 / CCh 300

Mibefradil 20 / vehicle

2-APB 15 / CCh $1 \mathrm{mM}$

Vehicle / CCh $1 \mathrm{mM}$

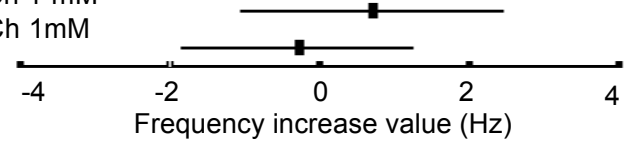

C

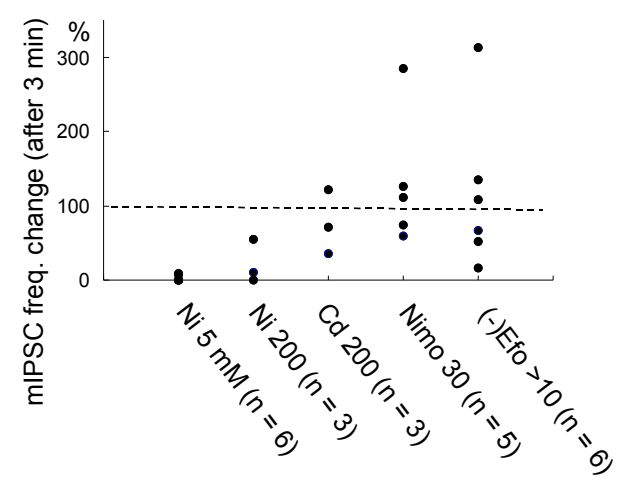

B

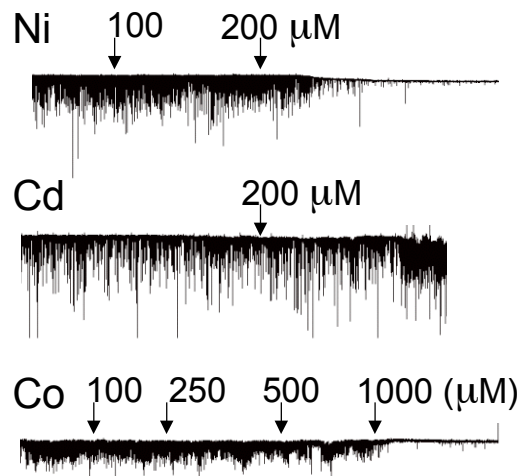

Mg $\quad \frac{10 \mathrm{mM}}{2 \mathrm{~min}} 400 \mathrm{pA}$
Nimo $30 \mu \mathrm{M}$

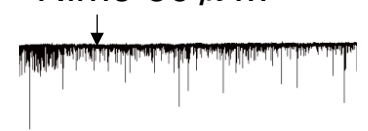

(-)Efo saturated

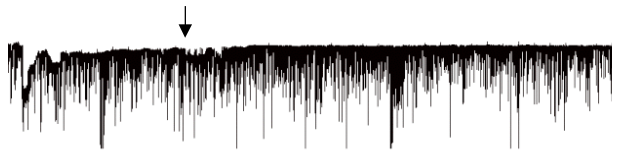

AgalV $(1 \mu \mathrm{M})+$ Cono VI $(1 \mu \mathrm{M})$

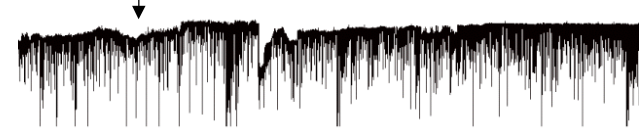

Figure 6 
A

Figure 7

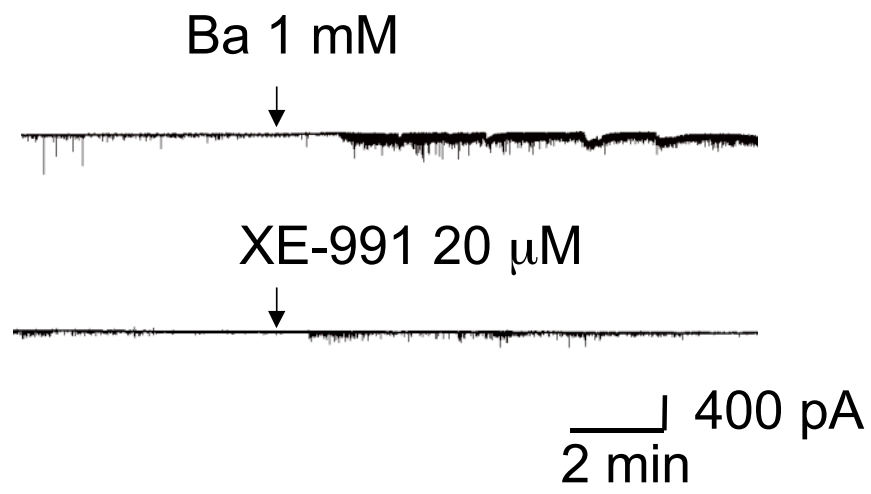

B

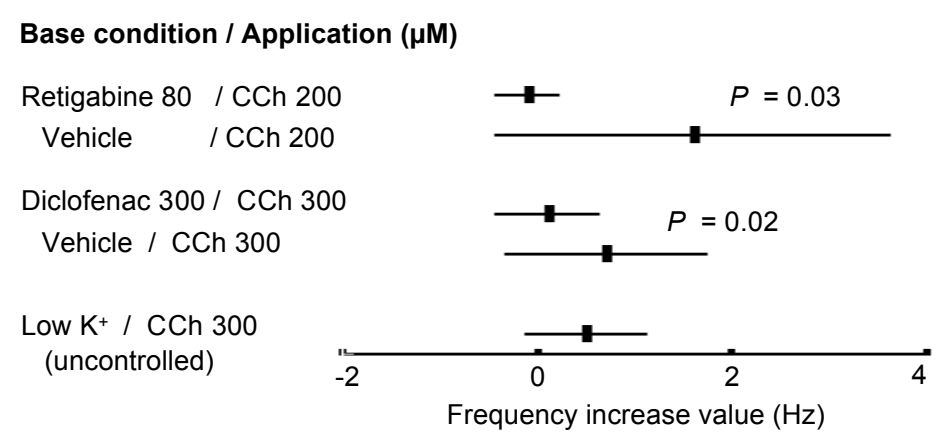


A

Figure 8

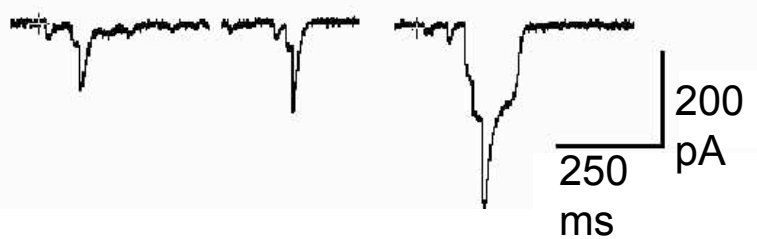

B
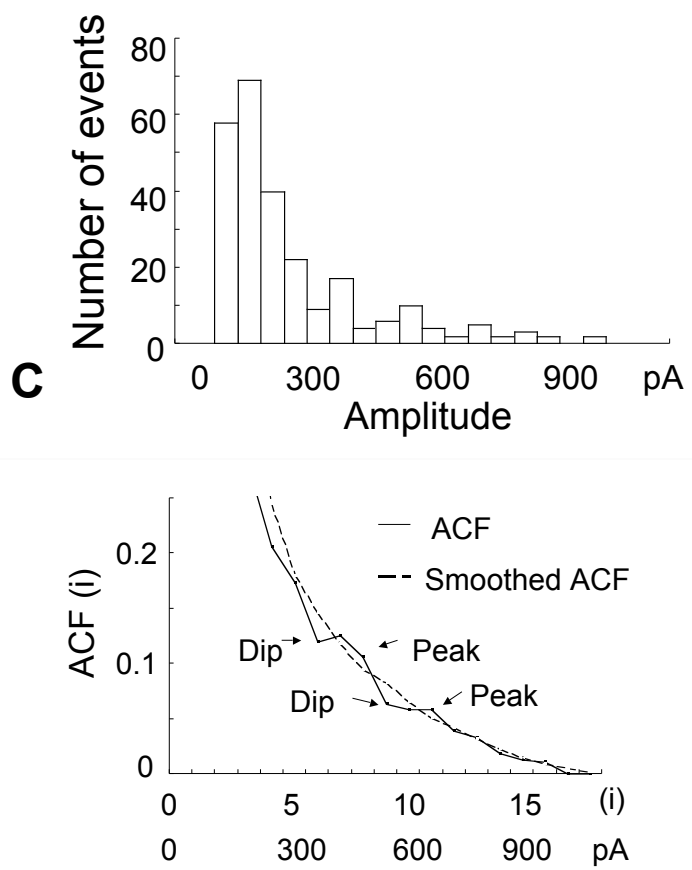


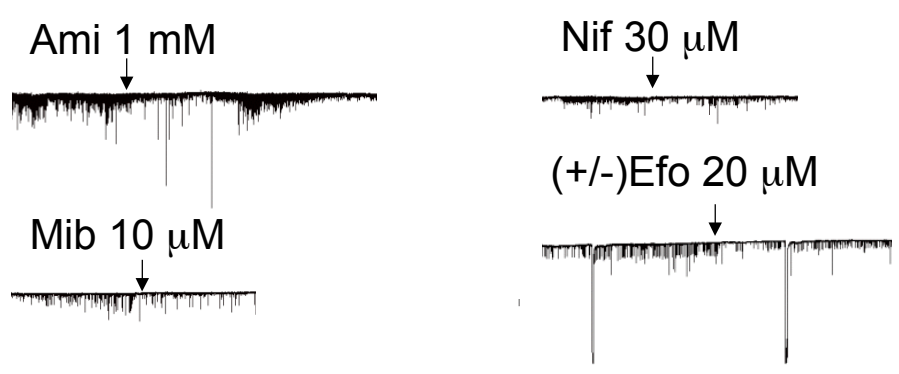

Snx $1 \mu M$

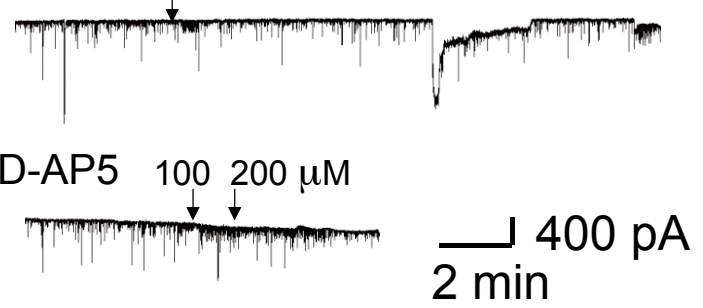

Supplementary Figure 